\title{
Relationship Networks and Earnings Informativeness: Evidence from Corruption Cases
}

\author{
Joseph P.H. Fan, Feng Guan, ZengQuan Li And Yong George Yang*
}

\begin{abstract}
The measurement difficulties arising from relationship-based business transactions can result in accounting opacity. We test this hypothesis by exploiting a natural experiment. Using a sample of firms that were networked with 45 high-level Chinese bureaucrats involved in corruption scandals between 1996 and 2007, we examine the patterns in the earnings informativeness of these firms before and after the exogenous break of the networks. We predict that the costs and benefits of business-politics relationships, which are not measurable by the current accounting systems, diminish the ability of accounting earnings to track a firm's economic performance. In turn, a break in a political relationship due to anti-corruption enforcement reduces the measurement noise and improves the earnings informativeness. We find that, relative to the matched control firms, there is indeed a significant increase in the earnings informativeness of the networked firms following the public exposure of a scandal. Robustness tests fail to show that the documented improvement in the earnings informativeness is primarily due to systematic changes in the firms' earnings management behavior or disclosure policies.
\end{abstract}

Keywords: earnings informativeness, political networks, corruption, China

\section{INTRODUCTION}

Studies find that accounting numbers in emerging markets are less informative about firms' economic value than the numbers in developed economies (Ball et al., 2000,

\footnotetext{
*The first author is from the Faculty of Business Administration and Institute of Economics and Finance, The Chinese University of Hong Kong, Shatin, NT, Hong Kong. The second and third authors are from the School of Accountancy, Shanghai University of Finance and Economics, GuoDing Rd. 777, YangPu District, Shanghai, China 200433. The fourth author is from the School of Accountancy, The Chinese University of Hong Kong. The authors appreciate valuable comments from Lawrence Brown, Ying Cao, Mara Faccio, Xiaohong Liu, Chul Park, Joseph Piotroski, Gordon Richardson, the workshop participants at the University of Hong Kong and 2009 AAA Annual Meeting (New York), and especially the Editor Martin Walker and an anonymous referee. The authors acknowledge the financial support of the Research Grants Council of the Hong Kong SAR government (CUHK442909). Zengquan Li acknowledges the funding support of the Program for New Century Excellent Talents in University (No. NCET-12-0899), NSFC (No. 71372041), the MOE Project of the Key Research Institute of Humanities and Social Science in University (No. 13JJD790019), the Program for Innovative Research Team of Shanghai University of Finance and Economics, and the MOE Project of Humanities and Social Science (No.13YJA790057). Yong George Yang acknowledges the funding support of the National Natural Science Foundation of China (No. 71272213). (Paper received August 2012, revised version accepted April 2014).
}

Address for correspondence: Yong George Yang, School of Accountancy, The Chinese University of Hong Kong, Shatin, NT, Hong Kong. e-mail: yyong@cuhk.edu.hk 
2003; Fan and Wong, 2002; Leuz et al., 2003; Bushman and Piotroski, 2006; Bushman et al., 2006; Leuz and Oberholzer-Gee, 2006; DeFond et al., 2007). Poor corporate governance and weak protection of investor rights are proposed as the main factors leading to this accounting opacity. In environments with weak legal systems, corporate insiders can distort accounting information to cover their expropriation of interests from common investors.

However, the prevalence of relationship networks formed by familial, social and political ties is an under-investigated factor that could also play an important role in explaining accounting numbers' lack of informativeness in emerging markets. These networks provide the parties involved with trust and high-powered incentives (Williamson, 1985) and help to enforce contracts (Klein and Leffer, 1981), thereby constituting critical input of and adding significant value to the firm (Fisman, 2001; Leuz and Oberholzer-Gee, 2006; Allen and Babus, 2009). Relationship networks pose challenges to the current accounting systems. The ability of earnings to reflect changes in firm value is particularly weak because the costs and benefits of these networks cannot be properly measured.

Although difficult to accurately measure, political relationships affect a firm's growth potential and the economic value of its standard assets as well as the value of the whole firm (Jenkins et al., 2009). For example, the sales and therefore the value of a factory are very likely to depend on whether the factory is owned by a politically connected entrepreneur who can secure future business from the government. Nonetheless, the value of these relationships is typically not reflected in the book value of intangibles or other assets in the accounting system, but is rather manifested in the privileged granting of governmental contracts or in preferential treatment by the government's future policies. In addition, the costs incurred in cultivating these relationships are normally immediately expensed, but the benefits only materialize in the future, resulting in a mismatch between costs and benefits. Moreover, the economic rent can be risky, because it depends on the stability of the relationship and the political career of the connected bureaucrat. Using Indonesia as a testing ground, Leuz and Oberholzer-Gee (2006) show that the profits associated with a political relationship can be risky in regions with severe political strife. This risk adds uncertainty to the rent obtained by the connected firm and, accordingly, influences investors' evaluation of the firm's earnings persistence. For the above reasons and according to the noise-in-signal model developed by Holthausen and Verrecchia (1988) and Kothari (2001) that is empirically supported by Teoh and Wong (1993) and Ou and Sepe (2002), we predict that firms connected to political bureaucrats have a lower level of accounting informativeness than unconnected firms.

It is difficult to empirically disentangle the accounting effects of political networks, due to, for example, the presence of severe endogeneity and the difficulty in establishing causality. We overcome these barriers by exploiting a natural experiment. We collect information on 45 high-level Chinese government officials who were charged with and punished for corruption and the managers of publicly traded firms that were connected with these bureaucrats through previously existing relationships or outright bribery. High-profile corruption cases are typically exposed during political strife or for other reasons that have little to do with the business of the networked firms (Fan et al., 2008). Enforcement against corruption effectively and unexpectedly breaks the networks between the accused bureaucrats and the firms/managers. Our hypothesis will be supported if we observe an improvement in the association between the 
accounting numbers and the firms' values following enforcement and the subsequent break of political networks.

Our treatment sample consists of two groups of firms. Bribing firms are firms confirmed in the public press to have paid bribes to corrupt officials. These firms represent the most conspicuous type of political connection and the sample is relatively small. We increase the power of our statistical tests and generalize the implications of our analysis by identifying the firms that are highly likely to have been connected with the corrupt bureaucrats through a prior job-related relationship or kinship, but were not directly linked with the corruption scandals in the public news. We label these firms as related firms.

We examine the change in the earnings informativeness of the treatment firms after their connections with the bureaucrats were broken by the exposure of the bureaucrats' corruption. We compare the treatment firms with matched firms that are similar in various dimensions but were not connected to the exposed bureaucrats. We measure the earnings informativeness using the annual-window earnings response coefficient (ERC) (Lev and Zarowin, 1999; Ball et al., 2000; Fan and Wong, 2002; Francis et al., 2005; Hanlon et al., 2008). Consistent with our hypothesis, we find that the treatment firms' ERCs significantly increase relative to their matched control firms following the exposure of the corruption scandals. This result is robust to controlling for factors that can affect the ERC, such as the firms' general disclosure policies.

We argue that the measurement issue associated with relationship networks generates the noise affecting the earnings informativeness. However, it is possible that the improvement of the earnings informativeness observed in our treatment firms is due to a lower level of earnings management after the corruption exposure. For example, when firms are connected with corrupt bureaucrats, they have greater incentives to manage their earnings to hide their rent-seeking activities, the disclosure of which may attract political and social scrutiny. We examine this possibility by comparing the politically connected firms' earnings management behavior before and after the exposure of the corruption scandals. The empirical evidence indicates no significant change in earnings management. Our main result is also robust to earnings measures that are not likely to be susceptible to earnings management.

This study contributes to the networks and earnings informativeness literature. Many studies show that networks facilitate an entrepreneur's access to important resources and markets (McMillan and Woodruff, 1999; Fisman, 2001; Johnson and Mitton, 2003; Khwaja and Mian, 2005; Faccio, 2006; Khanna and Thomas, 2009; Bunkanwanicha et al., 2009; also see Allen and Babus (2009) for a review of this body of literature). Networks are particularly important in emerging markets, in which formal institutions provide weak protection for business transactions. Even in developed countries such as the United States, networks can affect corporate investment and financing decisions (Cohen et al., 2007; Hochberg et al., 2007). However, the way in which networks constrain the ability of accounting systems to measure economic performance is only now attracting research attention. ${ }^{1}$ We provide early evidence of this constraint.

Our research complements a recent study by Chaney et al. (2011) that examines the effect of political relationships on accounting properties in an international setting.

1 For example, Bae and Jeong (2007) find that the value-relevance of earnings is smaller for firms affiliated with business groups in Korea. 
Chaney et al. show that firms with political connections report lower-quality earnings, as measured by the standard deviation and magnitude of the discretionary accruals. They reason that politicians are likely to provide protection for their connected companies and that low-quality accounting information is thus not penalized. Connected firms therefore have a lower incentive to improve the quality of the information that they disclose than unconnected firms. We examine the association between the accounting earnings and stock returns, and extend the research of Chaney et al. (2011) by showing how political networks affect investors' use of financial information in a capital market.

China provides an ideal testing ground for our hypothesis. Political networks are prevalent and important in the country's business sector, just as they are in many of the world's economies. The Chinese government periodically imposes tough anticorruption measures, which have resulted in numerous scandals involving high rank officials. These features allow us to compile a reasonably large sample, which helps to boost the power of our empirical tests and produce results that have international implications. China is not exceptional in terms of high-profile corruption. According to Transparency International's Corruption Perceptions Index, China ranked $80^{\text {th }}$ out of 174 countries in terms of its corruption level in 2012, coming after Sri Lanka $\left(79^{\text {th }}\right)$ and Cuba $\left(58^{\text {th }}\right)$, but before India $\left(94^{\text {th }}\right)$ and many other countries.

The evidence presented in this study also points to a potential limitation in the convergence of accounting standards, which is currently being promoted by the International Accounting Standards Board. Walker (2010) and Christensen, Lee and Walker (2007) suggest that different economies and different firms could have different needs for accounting systems. The optimal design of accounting standards involves the consideration of the institutional characteristics of the political and economic system. Our findings concur with this message and suggest that the extent to which a set of internationally uniform accounting standards can help investors to better understand their investment targets in different institutional settings remains far from clear.

The remainder of the article is organized as follows. Section 2 develops our main hypothesis and Section 3 introduces the research design. We discuss our empirical results in Section 4 and Section 5 summarizes our findings and concludes the research.

\section{PRIOR RESEARCH AND HYPOTHESIS}

The past several decades have witnessed increasing concern over the deterioration of the usefulness of financial information. For example, Steven Wallman, the thenSecurities and Exchange Commission commissioner, commented:

My concerns, then, are that there are a significant number of assets that are poorly measured through historical cost accounting and, more importantly, that we have entire categories of assets that are not recognized at all. And the problem is getting worse. In particular, it is the latter group of assets

- those that are not even recognized - that are the fastest growing and most important parts of most of our new firms (Wallman, 1995, p. 85).

Wallman used the intellectual property and human assets of service firms as examples of assets that are crucial to firms' operations but are omitted from their balance sheets. Rimerman (1990), Elliott (1995) and Stewart (1997) express similar sentiments. 
A number of studies follow these concerns and investigate whether the informativeness of the information provided in financial statements has decreased over time. Notably, Lev and Zarowin (1999) find evidence that the usefulness of reported earnings, cash flows, and the book values of equity deteriorated between 1978 and 1996. They attribute this deterioration to the technological and economic changes driven by innovation and deregulation and to the mismatch between the costs and benefits of the investments causing these changes. For example, large investments, such as those in research and development $(\mathrm{R} \& \mathrm{D})$ and restructuring, are immediately expensed, although their benefits are not recorded until later and hence are not matched to their costs. Lev and Zarowin (1999) supplement their findings by using $\mathrm{R} \& \mathrm{D}$ to test their argument that the accounting of intangibles is the greatest failure of the current financial reporting systems tracking firm value and performance. Considering both the earnings and book values, Collins et al. (1997) find that although the combined value-relevance of the earnings and book values slightly increased, the incremental value-relevance of earnings declined between 1953 and 1993. They show that the increasing intensity of intangibles partially explains this temporal change. Francis and Schipper (1999) report similar findings using a different methodology. Graham et al. (2003) find that fair value disclosures contain incremental information relative to that in the equity method book value and the equity method reported income.

The concerns over the deficiency of the current reporting systems in properly accounting for intangibles have motivated several studies to investigate the valuerelevance of specific intangible assets. For example, Barth et al. (1998) find that brand value estimates are positively related to stock prices. Ittner and Larcker (1998) document a positive relationship between customer satisfaction measures and future accounting performance, and find that the public announcement of these measures is associated with a significant market reaction. Lev and Sougiannis (1996) show that stock prices are positively related to R\&D assets. Aboody and Lev (1998) show that stock prices are positively related to software development cost assets capitalized under SFAS No. 86. Barron et al. (2002) study the consequences of intangibles' influence on the value-relevance of accounting information. They provide evidence suggesting that analysts supplement firms' financial information by placing greater weight on their own idiosyncratic information when forecasting the earnings of firms with significant intangible assets. Kanodia et al. (2004) find that the necessity to separately identify intangibles increases with their significance to the firm value.

The findings of this study both complement and extend this body of literature. We investigate the effect on the earnings informativeness of an intangible factor that plays a significantly more important role in affecting the firm performance and value in emerging markets than the intangibles explored in previous research - the relationship-based assets. Relationships in political networks are critical to firm survival and success in emerging markets (Fisman, 2001; Charumilind et al., 2006; Faccio, 2006; Claessens et al., 2008). Politically connected firms gain a competitive edge through relaxed regulatory scrutiny, preferential treatment in competitions for government contracts, reduced taxation, and privileged access to key markets and to resources such as financing, land and electricity. However, firm owners must make substantial investments to build and maintain political relationships.

The dependence of business dealings on political and other types of relationships affects the ability of accounting numbers to measure the firm value. It is difficult for 
a firm to match the benefits generated from a relationship with the costs incurred to cultivate that relationship, as is required of other assets by the accounting standards of many countries, including those of China. The costs are usually incurred long before the benefits materialize and they are either not recognized as corporate expenses or the full amount is immediately recorded as an operating expense. Anecdotal evidence indicates that these costs can be substantial, relative to the firms' operating revenues. Among our sample corruption cases, for example, the bribes paid often amounted to more than US $\$ 1$ million and the largest bribe totaled more than US\$ 70 million. ${ }^{2}$

A relationship can distort the value of other assets. For example, a firm may purchase and sell standard assets at abnormal prices because these transactions are a means to build or capitalize on a relationship with a bureaucrat. Once these assets are in place, their productivity and value depend on the relationship. If the relationship strengthens or weakens, the economic value of the standard assets deviates from their book value. Accordingly, the ability of a firm's accounting earnings - which are derived from the book value of its assets - to track its economic performance is hampered.

Firms' dependence on relationships adds noise and uncertainty to their accounting earnings and thus reduces the informativeness of these earnings. As noted by Leuz and Oberholzer-Gee (2006), the rent obtained from a political connection carries a risk related to the political career of the bureaucrat with whom the firm has the connection. Using Indonesia as a setting, Leuz and Oberholzer-Gee (2006) find that once a firm loses its political connection due to the downfall of the government with which it is affiliated, it is very difficult for the firm to establish connections with the new regime. This risk is also likely to be significant for bureaucrats in China because the Chinese government has recently pushed its anti-corruption campaign. According to information released by the Central Commission for Discipline Inspection of the Communist Party of China (CPC), in the first 11 months of 2009, 106,626 bureaucrats were investigated and penalized under CPC rules, 2,231 of whom were further prosecuted and indicted on criminal charges related to embezzlement and bribery. Among those punished, 3,743 were middle-level (the top officials of a county) or higher-level officials capable of significantly influencing the operation of the firms located in their jurisdictions. This political risk adds significant uncertainty to the economic rents obtained by connected firms, affecting investors' assessments of the persistence of their earnings and profitability.

From an investor's perspective, the measurement issues related to political relationships are likely to result in noisier earnings for firms with political networks than firms without such networks. Using the noise-in-signal model proposed by Holthausen and Verrecchia (1988) and Kothari (2001) and applied in Teoh and Wong (1993, p. 350), we predict that the ERCs for networked firms will improve after legal prosecution effectively destroys the firms' political networks.

A potential confounding factor for the above prediction is the value-enhancing effect of political networks on the ERC. Political networks help firms to obtain bank financing with preferential terms and privileged access to businesses that are under the control or influence of connected bureaucrats. The networks can therefore improve the persistence of the connected firms' earnings and hence increase their ERCs, at least in the short term (Charitou et al., 2001). If this valuation effect dominates the

2 These officially disclosed numbers are typically considerably less than the actual numbers to avoid infuriating the public. 
noise effect, we will observe an overall decrease in the ERC when political networks break. The relative magnitude of these two effects is an empirical issue. We formally state our hypothesis as follows.

$\mathbf{H}_{1}$ : Ceteris paribus, the informativeness of a firm's accounting earnings improves after its political connections break.

We reason that it is the measurement and noise issues arising from the existence of political networks that drive the improvement of the earnings informativeness following the exposure of corruption. Alternatively, the managers of the networked firms may manipulate their earnings before the exposure of a scandal. ${ }^{3}$ For example, as connected bureaucrats grant them protections, networked firms face little pressure from the capital market to provide high-quality financial information and they bear a rather low level of litigation risk for managing their earnings (Chaney et al., 2011). Networked firms have incentives to hide the abnormal profits they derive from their political connections. After the exposure of the corruption scandals of these bureaucrats, the incentives and the ability of the formerly networked firms to manage their earnings will be weakened and greater earnings informativeness will be observed (Bao and Bao, 2004; Wieland et al., 2013; Wiedman and Hendricks, 2013).

How earnings properties change after a break in political relationships is still under debate. New incentives for managers to manage earnings may arise. The managers of previously connected firms may attempt to understate their earnings to avoid public attention, especially just after the exposure of a corruption scandal. However, without the protection and preferential treatment of bureaucrats, some of these firms will depend more heavily on the market to win the confidence and trust of their investors and clients than prior to exposure. They will be incentivized to window-dress to display better financial results. Supporting this view, Wang and Yung (2011) find that state-owned enterprises have lower levels of earnings management than privatelyowned firms in China. The direction of the net change in earnings management after the exposure of corruption scandals is thus unclear and its effect on the earnings informativeness is still an open question. We examine this issue in our tests below.

\section{RESEARCH DESIGN}

Cross-sectional tests of the effects of political networks on accounting informativeness typically suffer from endogeneity problems. The financial opacity may facilitate the building of political relationships, rather than the reverse. Political relationships may also be related to the state variables that are associated with firm earnings informativeness. We mitigate these concerns by introducing shocks to a set of politically connected firms that break their political connections. We then examine how the earnings informativeness of these firms changes after the shocks, relative to the changes in a set of matched control firms that are unaffiliated (or at least only affiliated to a lesser extent on average) with the exposed political network.

3 Prior research (e.g., Hui et al., 2014) shows that fraudulent earnings numbers are discounted by the market, leading to a low ERC. 
The shocks we introduce are corruption scandals involving high-ranking government officials. The managers of a number of publicly traded firms are affiliated with these bureaucrats through personal connections. Anti-corruption enforcement is exogenous for connected firms - it is top down from the central government, politically motivated, and has little to do with the business sector. The enforcements are unanticipated, leaving little time for the firms to adjust their relationships and policies. The exposure of corruption effectively breaks a firm's connection with their involved bureaucrat, yet does not directly affect and is not affected by the firm's accounting policies. Therefore, any change in the firm's earnings informativeness is most likely due to the break of the political relationship. The matching approach further controls for time-varying factors that may affect both connected and nonconnected firms (Hanlon et al., 2008).

\section{(i) Sampling Procedure and Identification of Political Connections}

We compile a set of corruption cases involving top officials at the provincial or central government level in China between 1996 and 2007 and identify the publicly listed firms that were connected with them. We focus on these relatively high-profile cases because a large amount of information is disclosed about them and the enforcement of such cases is primarily political and exogenous to the firms' business operations.

We identify 52 high-profile corruption cases that were exposed and investigated between 1996 and 2007 from official sources, such as the Excerpts of Disciplinary Cases of the CPC published by the CPC's Central Commission for Discipline Inspection and The Law Yearbook of China (1999-2007), supplemented with Internet searches. We exclude seven cases for which we are unable to identify a relationship with any publicly listed firms. Our final sample consists of 45 corruption cases. We end our sampling period in 2007, so that 5 years of financial data post-exposure are available for even the most recent case.

For each of the cases involving provincial level officials, we identify all of the publicly traded companies located in the corrupt bureaucrat's jurisdiction (province or direct administration city) around the corruption exposure date. For each of these companies, we then search the aforementioned governmental publications and the Internet for news about the investigation and any ensuing prosecutions to determine whether any of the company's senior managers, directors or controlling shareholders bribed the bureaucrat in question. For each case involving central government or national bank officials, we determine whether the managers of publicly listed firms anywhere in the country were reported to have bribed the official concerned. Ninety-two firms and their managers are identified as having made bribes in the 45 corruption cases considered and are termed the bribing firms or bribers.

Although anti-corruption enforcement is typically driven by political reasons, it is possible that the revealed involvement of the bribing firms in the scandals indicates that such enforcement is not completely exogenous to the firm. We therefore identify a separate set of firms that were potentially connected to the corrupt officials but were not exposed as bribers or otherwise found to be involved in the corruption scandal. For each company located in the jurisdiction of a bureaucrat exposed as corrupt, we search its initial public offering prospectus and annual reports prior to the corruption exposure date to determine whether any senior managers or directors of the firm were a family member of or had a close job affiliation with the bureaucrat in question. A 
manager/director is identified as having had a close job affiliation with the bureaucrat if he or she worked in that bureaucrat's governmental unit as a same-level colleague or an immediate subordinate. We identify 143 firms related to the 45 officials exposed in the corruption scandals, termed related firms.

The bribing and related firms are together referred to as connected firms. We may have missed some bribing or related firms because our classification is constrained by publicly available information. These classification errors will add noise to our tests and are likely to bias us against finding significant results.

The firms that remain after the screening process are unlikely to have been affiliated with the corrupt bureaucrats either directly through political or familial relationships or indirectly through business ties. We select our matched control firms from this group. It should be noted that these firms may well have been connected to other governmental bureaucrats. However, as these bureaucrats were not involved in the corruption scandals in our sample period, any relationships with them would not change the firms' earnings informativeness patterns around the corruption events considered here.

We control for firm characteristics, such as the size, location and industry, and the changes in macro-economic factors that may affect the earnings informativeness by matching an unconnected firm to each of our treatment firms (bribing and related firms). We partition all of the publicly listed companies in China into five equally sized groups based on the value of their total assets at the end of the year prior to the corruption scandal exposure (i.e., event) date. For each treatment firm involved in the scandal, we select a matching firm that belongs to the same size group as the treatment firm in the event year, belongs to the same industry and is located in the same province or a geographically adjacent province if the same providence requirement does not yield a valid match. If more than one firm qualifies as a match, then we choose the firm with the closest total assets value to the treatment firm. If no firm qualifies as a match, then we relax the industry membership constraint and impose only the locality condition. If we still cannot find a match, then we relax the locality constraint and impose only the industry membership condition. We prioritize the locality condition because the strength of a local bureaucrat's influence is more likely to be related to jurisdiction than to industry membership. We achieve matches for 215 of our 234 treatment firms without relaxing any constraints and an additional 18 by relaxing the industry membership constraint. We need to relax the locality condition to obtain a matching firm in only one case.

\section{(ii) Distinguish Earnings Measurement from Earnings Management}

We argue that a political network's effect on accounting properties is a measurement issue. However, the low earnings informativeness of politically networked firms may also, albeit not mutually exclusively, be the result of earnings management motivated by the connected firms' desire to cover up the political relationships or the lack of incentives to respond to the market's need for transparent disclosure (Chaney et al., 2011). Corruption induces earnings management and therefore adds noise to the earnings. The two effects differ, as earnings management functions as an intermediate step in a political connection's effect on the earnings informativeness, whereas the measurement issue affects the earnings informativeness directly. 
We investigate whether the change in earnings informativeness associated with the exposure of a corruption scandal is primarily due to a change in the earnings management behavior of connected firms. We use different proxies, such as the abnormal accruals derived from different models, related party transactions, and nonoperating items in the earnings, to measure earnings management and to examine whether there is a significant change in these variables in treatment firms following the exposure of the corruption scandals. We then repeat our main tests using earnings measures that are more difficult for management to manipulate. We use the earnings from continuing operations to calculate the earnings per share and earnings surprises that are used in this analysis.

\section{(iii) Variable Definitions and Model Specifications}

Following the literature (Ball et al., 2000; Fan and Wong, 2002; Francis et al., 2005; Hanlon et al., 2008), we use the long-window ERC as our measure of earnings informativeness. We also follow Easton and Harris (1991) and incorporate the information in balance sheets indirectly by including the earnings level in the model. The ERCs are estimated by the following regression.

$$
R E T_{i, t}=\beta_{0}+\beta_{1} \times \Delta E P S_{i, t}+\beta_{2} \times E P S_{i, t}+\varepsilon_{i, t},
$$

where $R E T_{i, t}$ is the 12-month buy-and-hold return cumulated from May of year $t$ to April of year $t+1$ for firm $i^{4}{ }^{4} P S_{i, t}$ is the annual earnings per share based on the bottomline net income deflated by the stock price at the beginning of the year, and $\triangle E P S_{i, t}$ is the change in the EPS. The estimates of $\beta_{1}$ and $\beta_{2}$ are our measures of the earnings informativeness. Our hypothesis $\mathrm{H}_{1}$ predicts that, on average, the ERC will increase in bribing and related firms after the exposure of corruption scandals involving their connected bureaucrats. Many of our sample firms lack a long time-series of stock return and financial data before and after the corruption scandals. We therefore pool all of our observations in the regression and use the data for the 5 years before and the 5 years after the corruption exposure year. We reduce classification errors by excluding the exposure year from the analysis. ${ }^{5}$ We use the change-in-change research design and include the control firms as the benchmark by using the following full model to test $\mathrm{H}_{1}$ :

$$
\begin{aligned}
R E T_{i, t}= & \beta_{0}+\beta_{1} \Delta E P S_{i, t}+\beta_{2} \Delta E P S_{i, t} \times S A M P_{i, t}+\beta_{3} \Delta E P S_{i, t} \times E X P_{i, t} \\
& +\beta_{4} \Delta E P S_{i, t} \times E X P_{i, t} \times S A M P_{i, t}+\beta_{5} E_{P S}+\beta_{6} E_{i, t} \times S A M P_{i, t} \\
& +\beta_{7} E_{i, t} \times E X P_{i, t}+\beta_{8} E_{i, t} \times E X P_{i, t} \times S A M P_{i, t}+\beta_{9} E X P_{i, t}+\beta_{10} S A M P_{i, t} \\
& +\beta_{11} E_{i, t} \times S A M P_{i, t}+\sum \text { Ind }+\sum \text { Year }+\varepsilon_{i, t},
\end{aligned}
$$

where the subscript $i$ denotes firm $i$, subscript $t$ denotes year $t$, SAMPequals 1 if the firm is a bribing or related firm, and 0 otherwise, and EXP equals 1 if the data year is after

4 China requires that all firms file annual reports by the end of April.

5 However, including the exposure year as the first post-scandal year in the analysis does not change our conclusions. In the reported results, we do not require firms to have non-missing data points in the specified window. When we impose this restriction in robustness tests, we naturally have a smaller sample size and in general we find even stronger results for most of the tests. 
(inclusively) the exposure year of the corruption scandal, and 0 otherwise. We use the industry fixed effects (dummy variables $I n d$ ) and the year fixed effects (year dummies Year) in all of the regressions and cluster by firm when calculating the standard errors for $t$-statistics.

Our main coefficients of interest are $\beta_{4}$ and $\beta_{8}$ in equation (2), which measure the change in the earnings informativeness of the bribing and related firms from before to after the corruption scandal exposure, using the change in the earnings informativeness of their matched control firms as the benchmark. To be consistent with $\mathrm{H}_{1}, \beta_{4}$ or $\beta_{8}$ must be significantly positive.

We also examine whether the change in the earnings informativeness following the exposure of a corruption scandal is due to a change in the earnings management behavior of the connected firms. We measure earnings management using the empirical proxies of discretionary accruals, below-the-line items, and related-party transactions.

We estimate the discretionary accruals using the modified Jones Model, adjusting for the performance (Kothari et al., 2005) and growth opportunities (Dechow et al., 2003). We run the following regression cross-sectionally for each year within each industry.

$$
\begin{aligned}
T A C_{j, t} / A_{j, t-1}= & \lambda_{0} / \mathrm{A}_{j, t-1}+\lambda_{1}\left(\Delta S_{j, t}-\Delta R E C_{j, t}\right) / A_{j, t-1}+\lambda_{2} P P E_{j, t} / A_{j, t-1} \\
& +\lambda_{3} R O A_{j, t}+\lambda_{4} \operatorname{Tobin}_{j, t}+\mu_{j, t},
\end{aligned}
$$

where the subscript $j$ denotes the firm $j$, subscript $t$ denotes the year $t$, and $T A C_{j, t}$ is the total accruals, calculated by $\triangle C A_{j, t-} \triangle C L_{j, t_{-}} \triangle C A S H_{j, t}+\triangle S T D_{j, t-} D E P_{j, t,}$, in which $\triangle C A$ is the change in current assets, $\triangle C L$ is the change in current liabilities, $\triangle C A S H$ represents the change in cash and cash equivalents, $\triangle S T D$ is the change in the debt included in the current liabilities, and $D E P$ represents the depreciation. In equation (3), $A$ is the total assets; $\Delta S$ is the change in sales; $\triangle R E C$ denotes the change in the accounts receivable; $P P E$ is the property, plant and equipment; $R O A$ is the return on assets; and Tobin $Q$ is Tobin's $Q$ calculated by (market value of equity + book value of the total liabilities) / total assets.

As connected firms may have incentives to manage their earnings upward or downward, depending on their actual situations and reporting needs, we use the absolute value of the residual $\mu_{j, t}$ from regression (3), labeled $A D A$, as a firm-year specific earnings management measure. We also use the signed value of the discretionary accruals to explore whether there is any systematic pattern in the directional earnings management after the exposure of corruption.

According to Chen and Yuan (2004) and Haw et al. (2005), Chinese firms also use below-the-line items to manage their earnings. We measure this type of earnings management using the absolute value of the non-operating income scaled by the sales revenue $(A N O I)$. Similarly, we also use the signed value of the non-operating income $(N O I)$.

Earnings management can also be represented by the sales from related-party transactions $(R P T)$. Jian and Wong (2010) find that Chinese firms use this type of transaction to prop up earnings to meet the exchanges' listing requirements for financial performance. Due to the lack of a commonly agreed model for the normal level of related-party sales, we follow Jian and Wong (2010) and use the previous year's 
proportion of total sales derived from related-party transactions as the normal level of related-party sales. We assume that any related-party sales above this level are used by firms to manage their earnings. The computation formula is as follows:

$$
R P T_{i, t}=\left[S A L E_{-} R P T_{i, t}-S A L E_{i, t} \times\left(S A L E_{-} R P T_{i, t-1} / S A L E_{i, t-1}\right)\right] / S A L E_{i, t},
$$

where the subscript $i$ indicates firm $i$; the subscript $t$ indicates year $t, R P T$ is the fraction of related-party sales intended for earnings management; $S A L E \_R P T$ is the gross related-party sales; and $S A L E$ is the sales revenue.

We examine whether the level of earnings management changes after the exposure of a corruption scandal by estimating the following regression equation:

$$
E M_{i, t}=\beta_{0}+\beta_{1} E X P_{i, t}+\beta_{2} S A M P_{i, t}+\beta_{3} E X P_{i, t} \times S A M P_{i, t}+\beta_{4} S I Z E_{i, t}+\beta_{5} L E V_{i, t}+V_{i, t},
$$

where $E M$ is our proxy for earnings management, taking the form of the absolute value of the discretionary accruals $(A D A)$, the percentage of abnormal related-party sales $(R P T)$, or the absolute value of the non-operating income as a percentage of sales (ANOI). SIZE is the logarithm of the total assets and $L E V$ is the leverage ratio defined as the total liabilities divided by the total assets.

A significantly positive (negative) coefficient $\beta_{3}$ will suggest that, relative to the matched control firms, there is a higher (lower) level of earnings management among connected firms after the exposure of corruption than before the exposure.

\section{EMPIRICAL RESULTS}

\section{(i) Descriptive Statistics}

In Table 1, we report the details of the 45 corruption cases, the scandal exposure dates, the name, province and position of each of the bureaucrats involved, the sentences and the number of bribing firms (92) and related firms (143). The corruption scandals and sample firms are distributed across the 1996-2007 period and span China's regions. ${ }^{6}$

Table 2 illustrates the industry distribution of the connected firms. These firms are distributed across 21 broad industry categories. It is no surprise that "Equipment and Instrument" (32), "Petroleum, Chemical and Plastics" (25), "Electricity, Gas and Water" (21), and "Real Estate" (13) are among the industries with the most firms networked with corrupt bureaucrats, as their businesses are either heavily influenced by governmental policies or are directly monopolized by the government.

Table 3 compares the dimensions of the financial attributes of the treatment firms and their matched counterparts, such as the cumulative stock return (RET), level and change in the earnings (EPS, $\triangle E P S)$, growth opportunity (TobinQ), leverage $(L E V)$, firm size $(S I Z E)$, and stock return volatility (STDRET). Prior research shows that the final four attributes affect our earnings informativeness proxy, the ERC (see Kothari, 2001, for a review). All of the variables are measured at the end of (for stock variables)

6 Case No. 40 involves a relatively large number of bribing firms. We find that our conclusions are not materially affected by the exclusion of this case (untabulated). 


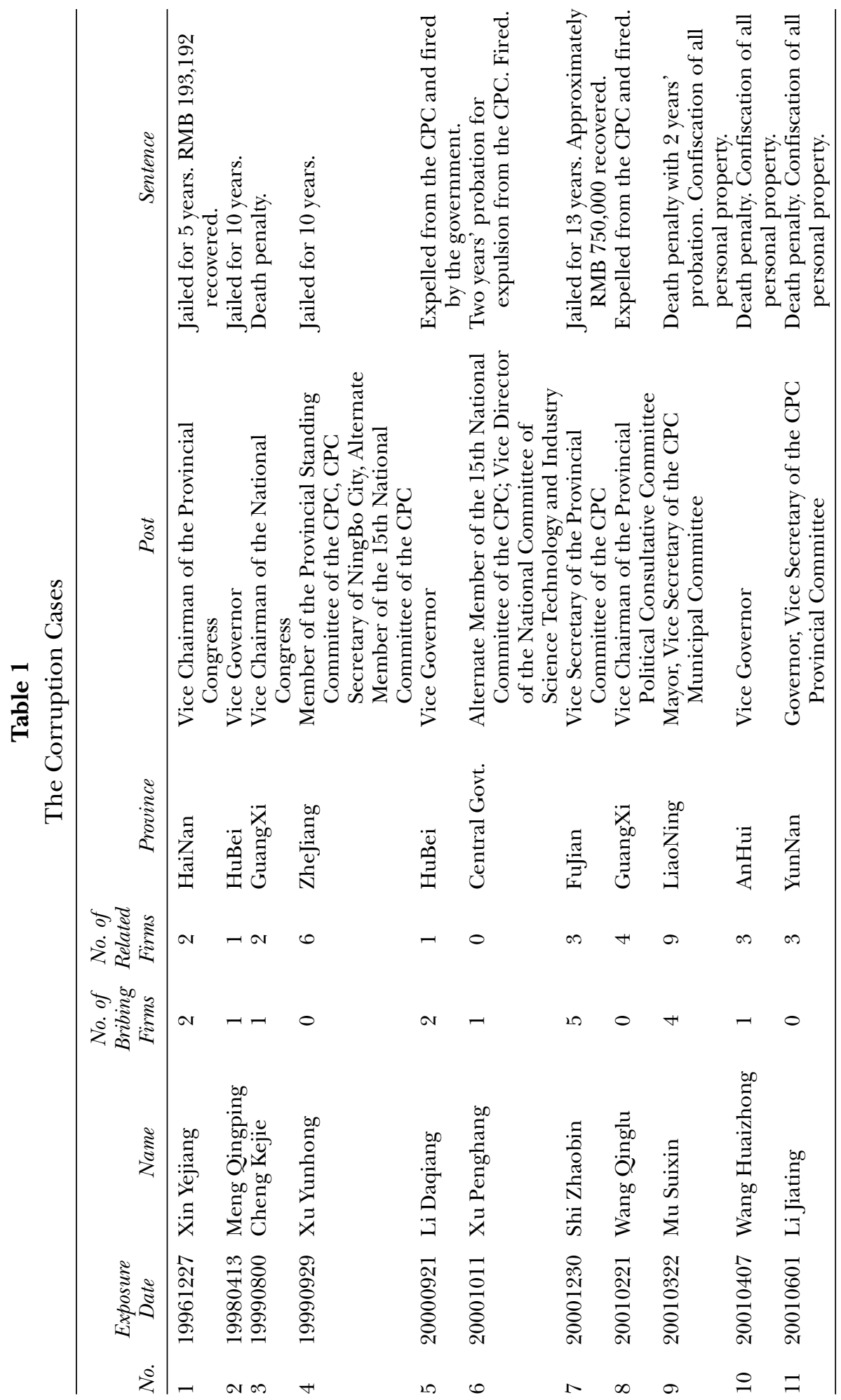




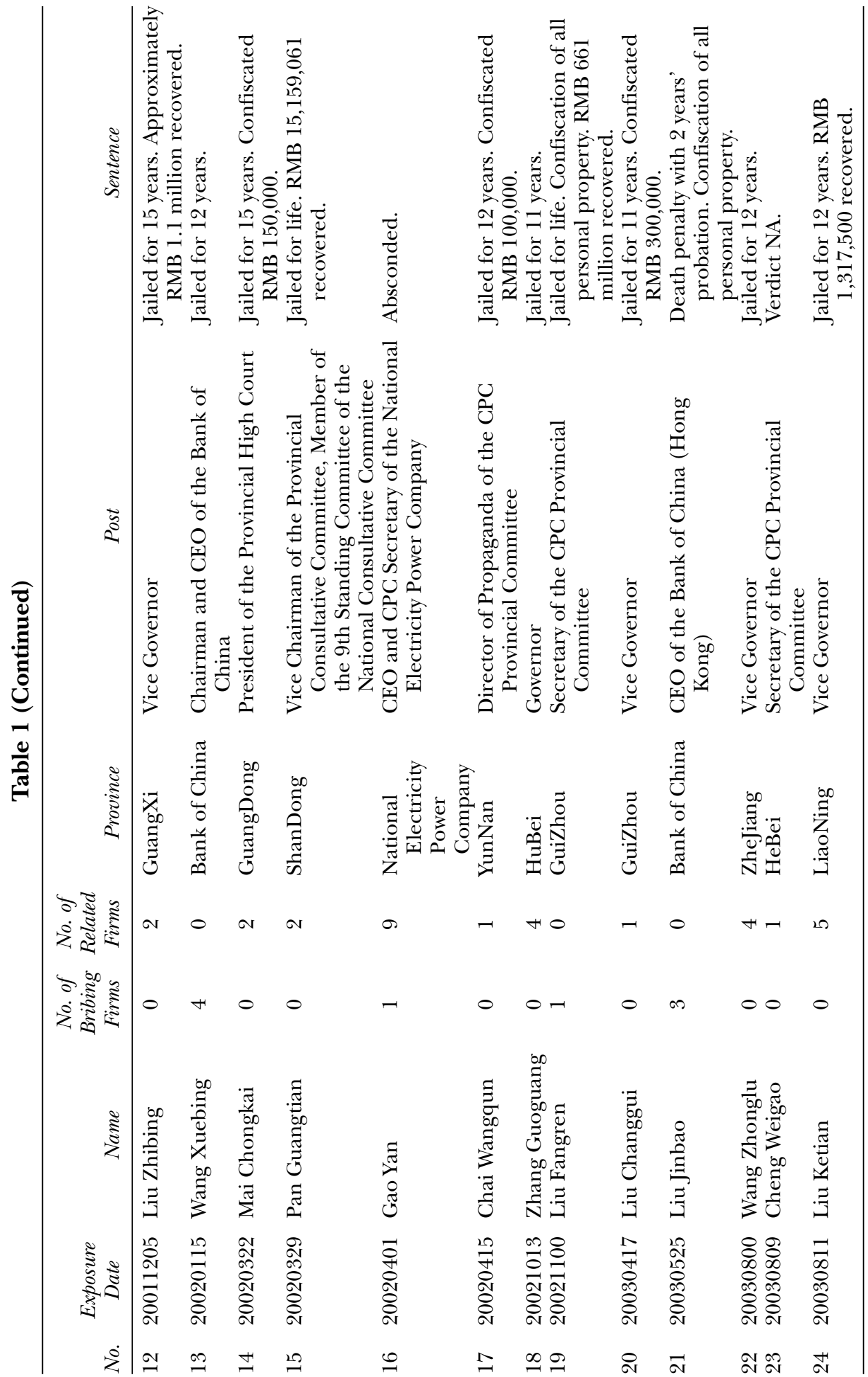




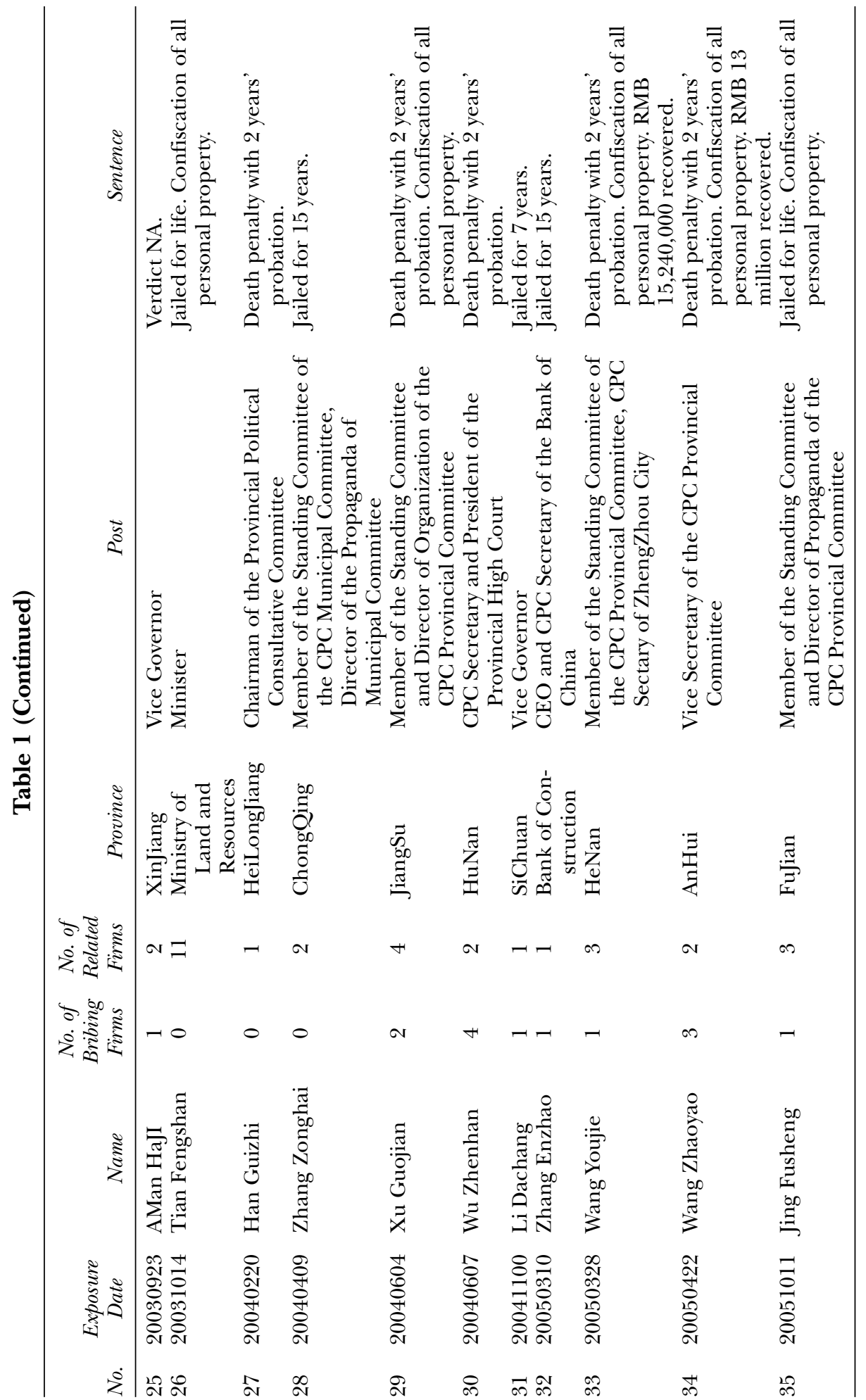




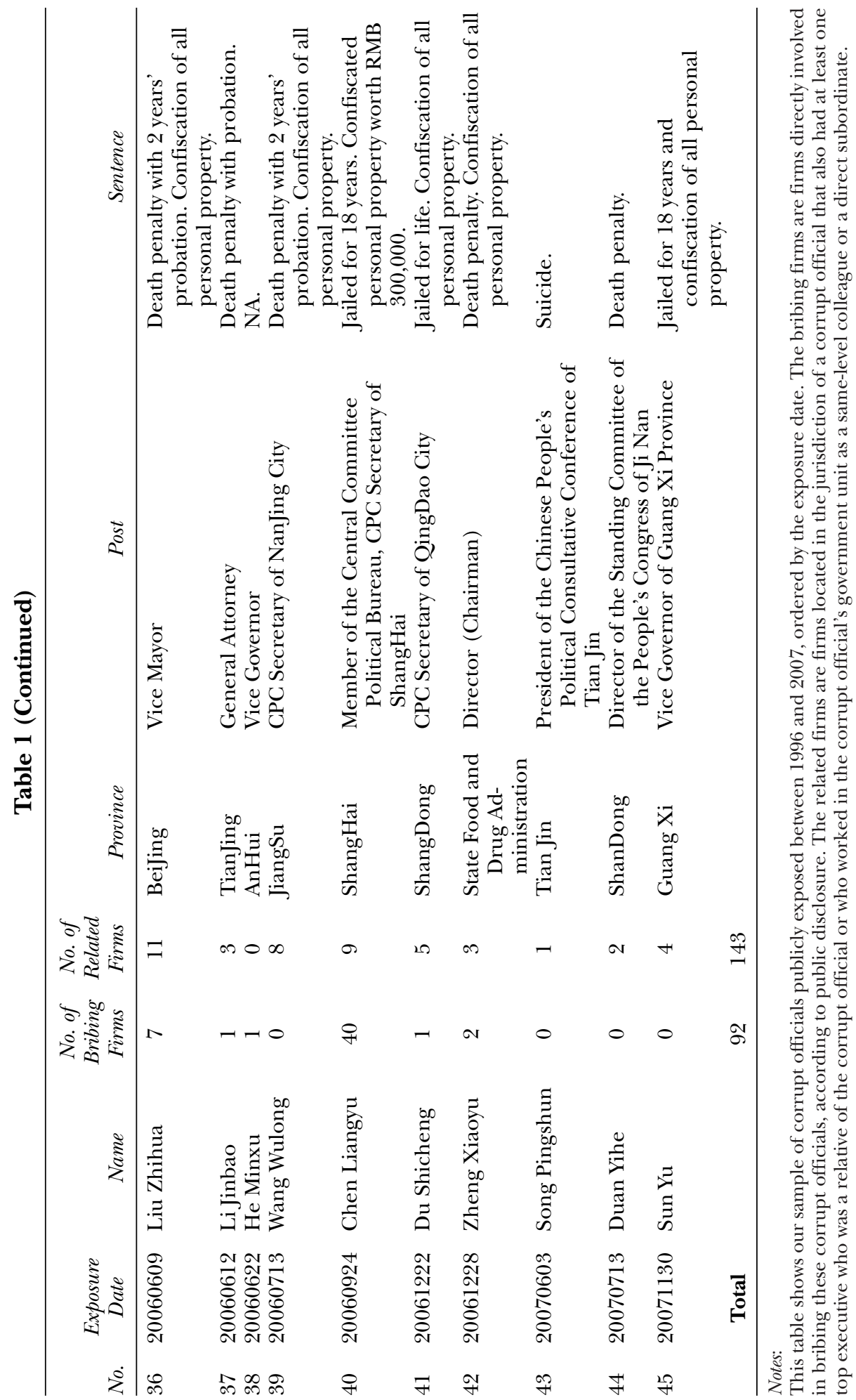


Table 2

The Industry Distributions of the Bribing and Related Firms

\begin{tabular}{llccc}
\hline No & \multicolumn{1}{c}{ Industry } & Bribing firms & Related firms & Connected firms \\
\hline 1 & Agriculture & 3 & 2 & 5 \\
2 & Mining & 1 & 1 & 2 \\
3 & Food and Beverage & 5 & 3 & 8 \\
4 & Textile and Clothing & 3 & 5 & 8 \\
5 & Timber and Furniture & 0 & 1 & 1 \\
6 & Paper and Printing & 1 & 0 & 1 \\
7 & Petroleum, Chemical and Plastics & 11 & 14 & 25 \\
8 & Electronics & 3 & 4 & 7 \\
9 & Metal and Non-metal & 4 & 10 & 14 \\
10 & Equipment and Instrument & 15 & 17 & 32 \\
11 & Pharmaceutical and Biological & 5 & 9 & 14 \\
12 & Electricity, Gas and Water & 6 & 15 & 21 \\
13 & Construction & 3 & 0 & 3 \\
14 & Transportation and Storage & 4 & 13 & 17 \\
15 & Information technology & 4 & 6 & 10 \\
16 & Wholesale and Retail & 10 & 12 & 22 \\
17 & Finance & 2 & 2 & 4 \\
18 & Real estate & 6 & 7 & 13 \\
19 & Service & 1 & 3 & 4 \\
20 & Communication and Culture & 1 & 0 & 23 \\
21 & Comprehensive & 4 & 19 & 235 \\
& Total & 92 & 143 & \\
\hline
\end{tabular}

Notes:

This table shows the industry distributions of the bribing and related firms. Bribing firms and related firms are both connected firms.

or over (for flow variables) the scandal exposure year. Other than the means of RET and STDRET and the medians of EPS and $\triangle E P S$, no significant differences exist between the two types of treatment firms (i.e., the bribing and related firms) and their matched control firms. This comparison gives us preliminary confidence that these potentially confounding factors will not significantly affect our subsequent regression results.

\section{(ii) Earnings Informativeness and the Breaking of the Political Relationship}

Table 4 columns I to III report the ordinary least squares regression results for model (2) using all of the connected firms and their control firms. In column I, we only consider the informativeness based on the change in the earnings. In column II we consider only the level of the earnings. In column III, we consider both.

Column I shows that the control firms have an average ERC of 4.270 (coefficient of $\triangle E P S$ ) over the 5-year period before the exposure years of the corruption scandals. However, the average ERC of the control firms decreases to 0.946 when measured over the 5 years after the scandal exposure years (coefficient of $\triangle E P S: 4.270+$ coefficient of $\triangle E P S \times E X P:-3.324)$. This large temporal change in the average ERC demonstrates the importance of the matching approach in our research design. It is not the objective of this study to understand why the ERCs of Chinese companies decrease over time. However, this temporal decrease is not unique to China. Lev and Zarowin (1999) find 
Table 3

The Characteristics of the Bribing and Related Firms

\begin{tabular}{|c|c|c|c|c|c|c|c|c|}
\hline \multirow[b]{2}{*}{ Variable } & \multicolumn{2}{|c|}{ Mean } & \multirow[b]{2}{*}{ Diff. Sig. } & \multicolumn{2}{|c|}{ Median } & \multirow[b]{2}{*}{ Diff. Sig. } & \multicolumn{2}{|c|}{ Std Dev } \\
\hline & Treatment & Control & & Treatment & Control & & Treatment & Control \\
\hline \multicolumn{9}{|c|}{ Panel A: Bribing Firms $(N=92)$} \\
\hline$R E T$ & 0.135 & 0.273 & * & 0.107 & 0.115 & & 0.456 & 0.528 \\
\hline$E P S$ & 0.003 & 0.018 & & 0.014 & 0.024 & $* *$ & 0.069 & 0.081 \\
\hline$\triangle E P S$ & -0.011 & -0.007 & & -0.002 & 0.002 & $*$ & 0.083 & 0.062 \\
\hline Tobin $Q$ & 2.148 & 2.009 & & 1.848 & 1.796 & & 1.364 & 0.955 \\
\hline$L E V$ & 0.494 & 0.465 & & 0.492 & 0.489 & & 0.183 & 0.169 \\
\hline SIZE & 21.336 & 21.235 & & 21.155 & 21.203 & & 1.220 & 1.085 \\
\hline STDRET & 0.024 & 0.024 & & 0.024 & 0.024 & & 0.007 & 0.006 \\
\hline \multicolumn{9}{|c|}{ Panel B: Related Firm $(N=143)$} \\
\hline$R E T$ & 0.164 & 0.145 & & 0.015 & 0.016 & & 0.164 & 0.145 \\
\hline$E P S$ & 0.015 & 0.023 & & 0.022 & 0.030 & & 0.015 & 0.023 \\
\hline$\triangle E P S$ & 0.001 & -0.007 & & 0.000 & -0.001 & & 0.001 & -0.007 \\
\hline $\operatorname{Tobin} Q$ & 2.162 & 2.069 & & 1.828 & 1.842 & & 2.162 & 2.069 \\
\hline$L E V$ & 0.487 & 0.458 & & 0.466 & 0.487 & & 0.487 & 0.458 \\
\hline SIZE & 21.370 & 21.366 & & 21.333 & 21.262 & & 21.370 & 21.366 \\
\hline STDRET & 0.025 & 0.023 & * & 0.024 & 0.023 & & 0.025 & 0.023 \\
\hline
\end{tabular}

Notes:

This table reports the differences in the mean, median and standard deviation (Std Dev) of the firm characteristics between the treatment firms and their matched control firms. The bribing and related firms together make up the treatment firms. The bribing firms are firms that were directly involved in bribing a corrupt official, according to public disclosures. The related firms are firms located in the jurisdiction of a corrupt official, which had at least one top executive who was a relative of the corrupt official or who worked in the corrupt official's government unit as a same-level colleague or a direct subordinate. All of the variables are measured over (for flow variables) or at the end of (for stock variables) the exposure year of the corresponding corruption case. $R E T=$ cumulative 12 -month stock returns; $E P S=$ earnings per share, scaled by the stock price per share; Tobin $Q=$ Tobin's $Q$ calculated by (the market value of the equity + the book value of the total liabilities)/the total assets; $L E V=$ leverage ratio defined as the total liability divided by the total assets; SIZE = logarithm of the total assets; and STDRET $=$ standard deviation of the daily stock returns calculated over the year. *,** and *** denote significance levels of $10 \%$, $5 \%$ and $1 \%$, respectively. "Diff. Sig." reports the significance level of the difference between the treatment and the control firms.

that the ERCs of US firms also decreased significantly from the 1970s to the 1990s. The average ERC of the treatment (connected) firms in the pre-scandal exposure period is 1.428 (coefficient of $\triangle E P S: 4.270+$ coefficient of $\triangle E P S \times S A M P .-2.842$ ), which is much lower than that of the control firms in the same period. After the exposure of the corruption scandals, the average ERC of the connected firms slightly decreases to 0.954 (coefficient of $\triangle E P S: 4.270+$ coefficient of $\triangle E P S \times S A M P$. $-2.842+$ coefficient of $\triangle E P S \times E X P:-3.324+$ coefficient of $\triangle E P S \times S A M P \times E X P: 2.850)$, which is very similar in magnitude to that of the control firms in the same period.

In Table 4 column II, in which we use the EPS level rather than the change in the EPS in the regression, we do not find a statistically significant change in the average ERC of the connected firms between the pre- to post-scandal exposure years, benchmarking against the control firms. As the stock returns measure the change in the firm value over the given period, the proper explanatory variables for the firm value should also be defined on a change basis and they should also reflect any new 


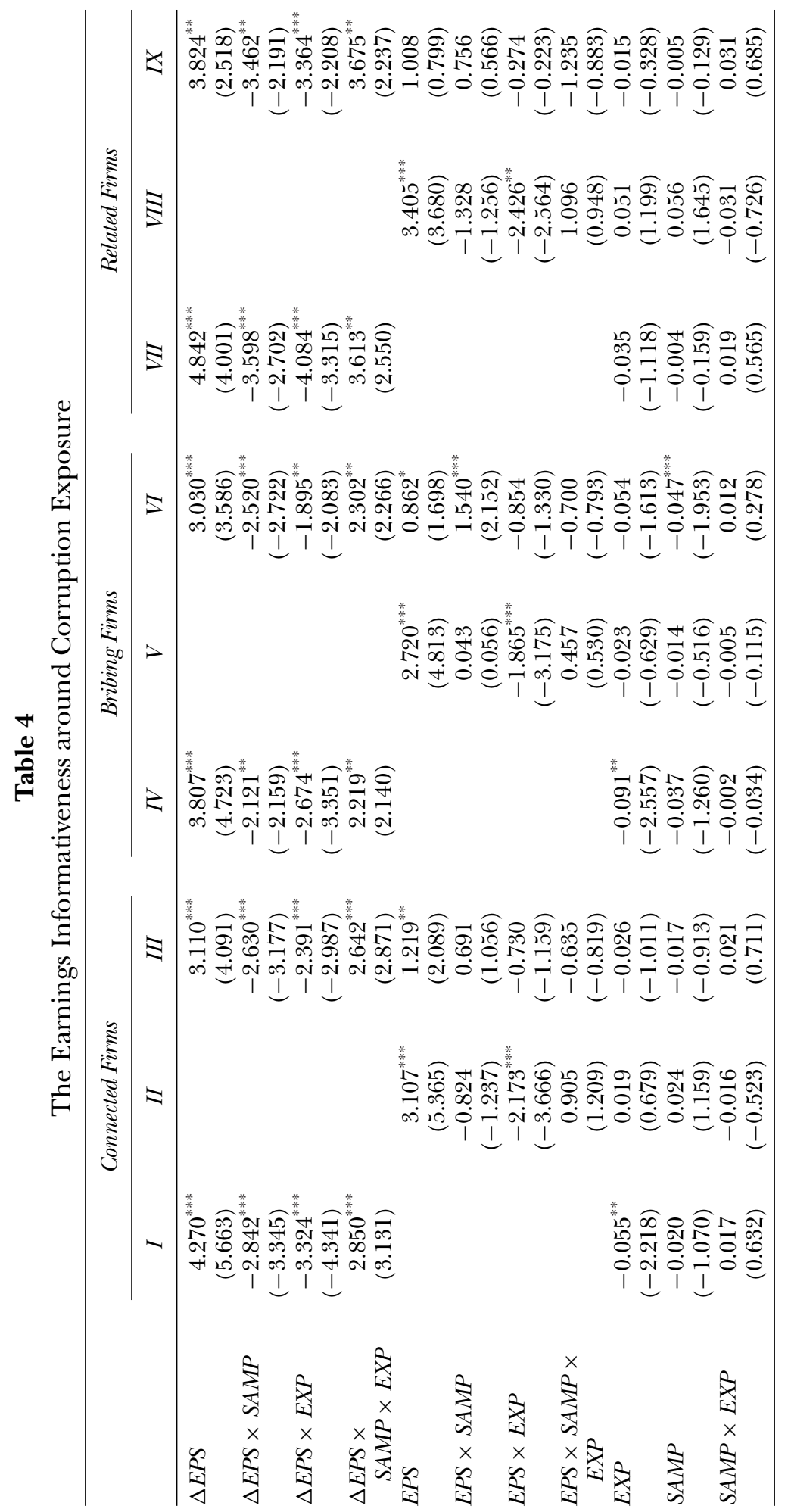




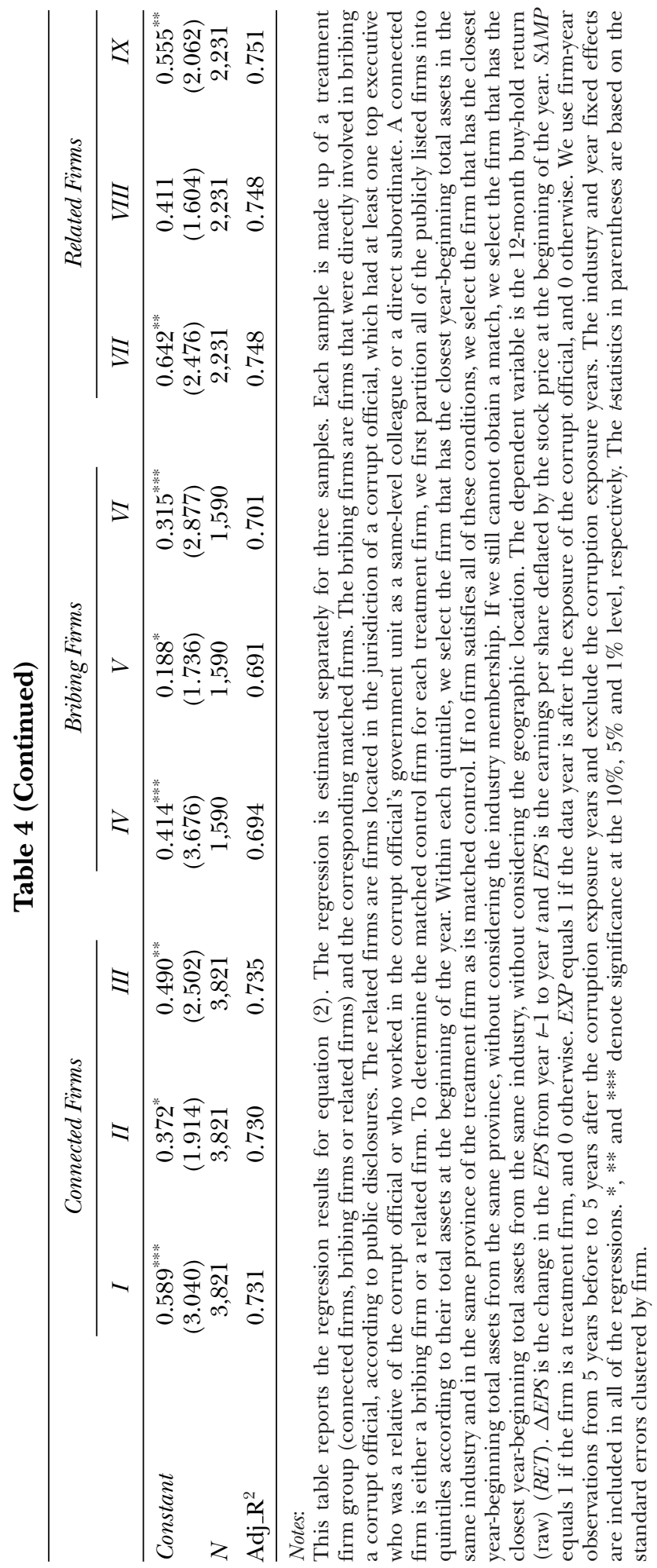


value-relevant information available to investors. However, given the strong persistence and time-series correlation of the earnings, a large portion of the information in the earnings level is stale and does not constitute new information to investors. Using the earnings level adds a substantial amount of noise to the latent construct of earnings innovation that is used in the model, which is likely to partially explain the insignificant result in column II.

In Table 4 column III, in which we include both the change in and level of the earnings, the findings are similar to the combination of the findings in columns I and II. As the change in the earnings is relatively superior in capturing the firm value change, we will focus our discussion on it from here forward. We still report the results based on the earnings level for completeness.

We perform the above regression analyses separately for the bribing (Table 4 columns IV to VI) and related (Table 4 columns VII to IX) firms. The results are in general very similar to those obtained using the combined sample.

In summary, Table 4 provides results consistent with our hypothesis $\mathrm{H}_{1}$ that the earnings informativeness of politically networked firms increases after their political networks break following the exposure of corruption scandals, compared to their matched control firms without those networks.

\section{(iii) Testing Earnings Management}

Although we argue that the increase in the earnings informativeness of connected firms from pre- to post-scandal exposure is primarily due to a reduction in the noise in their earnings, a decrease in earnings management may also play a role. Firms that were previously connected with a corrupt bureaucrat will no longer need to obfuscate their disclosures to hide their rent-seeking activities, leading to higher earnings valuerelevance (Marquardt and Wiedman, 2004).

Table 5 Panel A reports the regression results of equation (5), which is used to test the change in earnings management around the exposure of the corruption scandals. We conduct the regression separately for the three samples of treatment firms and their corresponding matched counterparts. We use firm-year observations from 5 years before to 5 years after the exposure of the scandals.

Table 5 columns I to III report the results using the absolute value of the discretionary accruals $(A D A)$ as a proxy for earnings management. The coefficient on $E X P \times S A M P$ is not statistically significant for the combined connected firms or the related firms. Relative to the control firms, there is no significant change in the level of the absolute discretionary accruals surrounding the scandal exposure events for these two samples of treatment firms. The coefficient of EXP $\times S A M P$ is marginally significantly negative (coefficient $=-0.017, t=-1.759$ ) for the bribing firms, which is consistent with the bribing firms being more cautious in their financial reporting because they are under close scrutiny from the public and regulators. The results based on the abnormal level of related-party sales $(R P T)$ are reported in columns IV to VI and the results based on the absolute value of the non-operating income (ANOI) are reported in columns VII to IX. None of the estimated coefficients for $E X P \times S A M P$ are statistically significant.

In Panel B of Table 5, we investigate whether there is a systematic shift in the direction of earnings management around the corruption exposure event. Columns I to III report results for the signed discretionary accruals as the dependent variable 


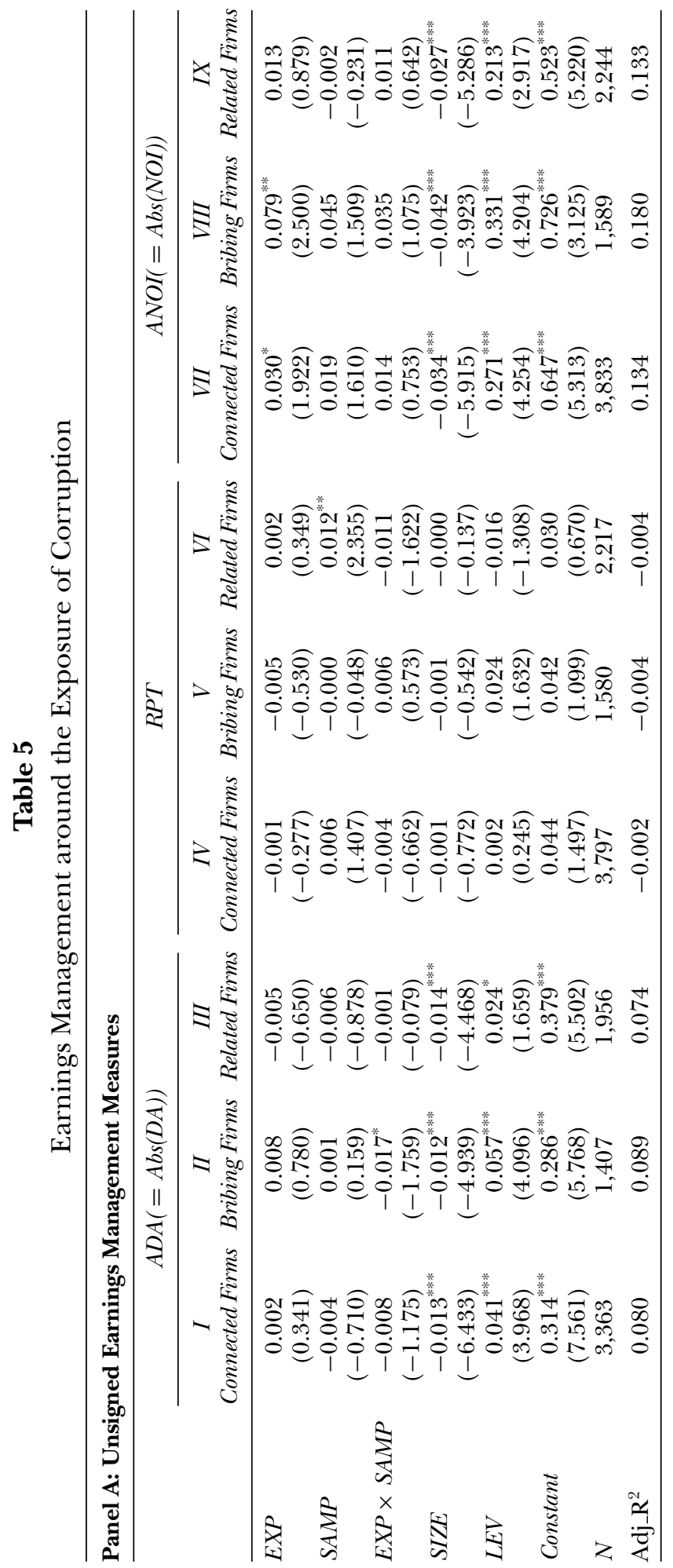




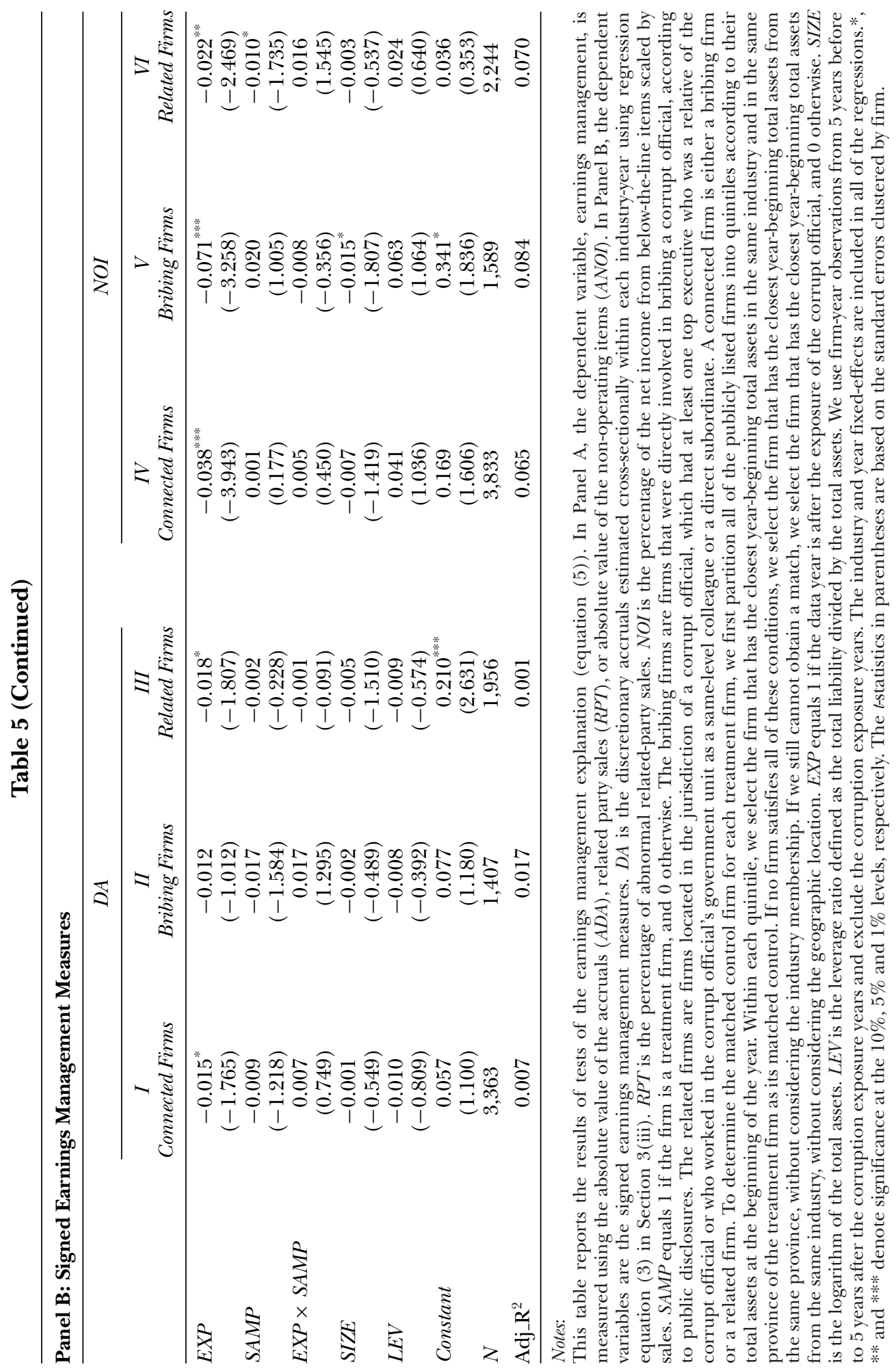


and columns IV to VI for the signed non-operating income. The interaction term $E X P \times S A M P$ is not statistically significant for any of the six model specifications.

The results in Table 5 therefore do not support the proposition that a change in earnings management explains the change in the earnings informativeness documented above.

\section{(iv) Additional Analysis of the Valuation and Measurement Effects}

As we discussed above, connections with governmental officials can have both a valuation effect, increasing the ERC, and a measurement effect, decreasing the ERC, on firms' earnings. Our results in Table 4 suggest that the measurement effect dominates the valuation effect. We shed additional light on this issue by examining the interaction of these two effects.

We predict that the measurement/noise effect of political networks is related to the firms' investment cycles. Political connections can have a substantial effect on the future cash flows of networked firms' investment projects. A longer investment cycle is therefore likely to cause a more severe mismatching problem between the investments in cultivating political networks and the benefits reaped from these relationships. Firms with a longer investment cycle are likely to have a greater improvement in their earnings informativeness after the disruption of their political networks than their control firms. The valuation effect in firms with short investment cycles will be relatively more prominent and will offset or even dominate the measurement effect. If this prediction is true, we will observe an insignificant or significantly negative change in the earnings informativeness after the corruption scandals. We follow Khan and Watts (2009) and use the industry average depreciation expense divided by the lagged total assets to measure a firm's investment cycle.

Table 6 columns I to III report the regression results of equation (2) for firms with relatively long (greater than the sample median) investment cycles. If the change in the earnings and the level of the earnings are separately included in the model, both of the three-way interaction terms are significantly positive. In column III, in which the change in and level of the earnings are both included in the model, the effect of the earnings level appears to be subsumed by the change and only the threeway interaction term for the change in the earnings is significant. The evidence is consistent with our prediction that the measurement effect dominates the valuation effect in firms with relatively long investment cycles. In contrast, in columns IV to VI we estimate the regression for firms with relatively short (smaller than the sample median) investment cycles. The three-way interaction terms for the change in the earnings are no longer statistically significant. Instead, the three-way interaction term for the earnings level, included alone or jointly with the change in the earnings, becomes significantly negative. The evidence therefore lends support to our prediction that the valuation effect will offset or even dominate the measurement effect in firms with relatively short investment cycles.

As the valuation and measurement effects are both embedded in the single construct of political connection, it is difficult to separately examine the two effects. We follow prior research (Khwaja and Mian, 2005; Fan et al., 2008) and predict that firms that rely more on external financing for investment extract more benefits from their political connections and that the valuation effect is likely to be particularly strong for these firms. The break of their political networks will therefore cause a 
Table 6

Analysis of the Valuation Effect and the Measurement Effect

\begin{tabular}{|c|c|c|c|c|c|c|}
\hline & \multicolumn{3}{|c|}{$\begin{array}{c}\text { Long Investment Cycle } \\
\text { (Investment Cycle }>\text { Sample Median) }\end{array}$} & \multicolumn{3}{|c|}{$\begin{array}{l}\text { Short Investment Cycle } \\
\text { (Investment Cycle }<\text { Sample Median) }\end{array}$} \\
\hline & $I$ & $I I$ & III & $I V$ & V & $V I$ \\
\hline$\triangle E P S$ & $\begin{array}{l}7.566^{* * * *} \\
(4.137)\end{array}$ & & $\begin{array}{l}5.383^{* * * *} \\
(3.297)\end{array}$ & $\begin{array}{l}2.705^{* * * *} \\
(4.077)\end{array}$ & & $\begin{array}{l}2.349^{* * * *} \\
(2.653)\end{array}$ \\
\hline$\triangle E P S \times S A M P$ & $\begin{array}{l}-6.461^{* * * *} \\
(-3.466)\end{array}$ & & $\begin{array}{l}-4.979^{* * *} \\
(-3.007)\end{array}$ & $\begin{array}{l}-0.145 \\
(-0.135)\end{array}$ & & $\begin{array}{l}-1.248 \\
(-1.209)\end{array}$ \\
\hline$\triangle E P S \times E X P$ & $\begin{array}{l}-6.037^{* * *} \\
(-3.334)\end{array}$ & & $\begin{array}{l}-3.772^{* *} \\
(-2.173)\end{array}$ & $\begin{array}{l}-2.022^{* * * *} \\
(-2.940)\end{array}$ & & $\begin{array}{l}-1.938^{* * *} \\
(-2.151)\end{array}$ \\
\hline $\begin{array}{l}\triangle E P S \times S A M P \times \\
\quad E X P\end{array}$ & $\begin{array}{l}6.069^{* * * *} \\
(3.289)\end{array}$ & & $\begin{array}{l}4.241^{* * *} \\
(2.403)\end{array}$ & $\begin{array}{c}0.057 \\
(0.051)\end{array}$ & & $\begin{array}{l}1.265 \\
(1.124)\end{array}$ \\
\hline$E P S$ & & $\begin{array}{l}5.280^{* * * *} \\
(3.985)\end{array}$ & $\begin{aligned} 2.152^{*} \\
(1.655)\end{aligned}$ & & $\begin{array}{l}1.943^{* * * *} \\
(4.008)\end{array}$ & $\begin{array}{c}0.456 \\
(0.727)\end{array}$ \\
\hline$E P S \times S A M P$ & & $\begin{array}{l}-3.537^{* * *} \\
(-2.566)\end{array}$ & $\begin{array}{l}-0.742 \\
(-0.552)\end{array}$ & & $\begin{array}{l}1.546^{* * *} \\
(2.010)\end{array}$ & $\begin{array}{l}2.458^{* * * *} \\
(2.924)\end{array}$ \\
\hline$E P S \times E X P$ & & $\begin{array}{l}-4.087^{* * * *} \\
(-3.080)\end{array}$ & $\begin{array}{l}-2.264 \\
(-1.546)\end{array}$ & & $\begin{array}{l}-1.070^{* * *} \\
(-2.127)\end{array}$ & $\begin{array}{c}0.182 \\
(0.281)\end{array}$ \\
\hline $\begin{array}{l}E P S \times S A M P \times \\
\quad E X P\end{array}$ & & $\begin{array}{l}3.567^{* * *} \\
(2.504)\end{array}$ & $\begin{array}{c}1.449 \\
(0.934)\end{array}$ & & $\begin{array}{l}-1.727^{* * *} \\
(-1.982)\end{array}$ & $\begin{array}{l}-2.645^{\text {**** }} \\
(-2.637)\end{array}$ \\
\hline$E X P$ & $\begin{array}{l}-0.094^{* * *} \\
(-2.844)\end{array}$ & $\begin{array}{c}0.030 \\
(0.650)\end{array}$ & $\begin{array}{l}-0.032 \\
(-0.694)\end{array}$ & $\begin{array}{c}0.008 \\
(0.232)\end{array}$ & $\begin{array}{c}0.054^{*} \\
(1.660)\end{array}$ & $\begin{array}{c}0.017 \\
(0.488)\end{array}$ \\
\hline$S A M P$ & $\begin{array}{l}-0.042^{*} \\
(-1.656)\end{array}$ & $\begin{array}{c}0.061 \\
(1.548)\end{array}$ & $\begin{array}{l}-0.004 \\
(-0.092)\end{array}$ & $\begin{array}{c}0.019 \\
(0.780)\end{array}$ & $\begin{array}{c}-0.000 \\
(-0.002)\end{array}$ & $\begin{array}{c}-0.029 \\
(-1.088)\end{array}$ \\
\hline$S A M P \times E X P$ & $\begin{array}{c}0.038 \\
(1.012)\end{array}$ & $\begin{array}{c}-0.044 \\
(-0.948)\end{array}$ & $\begin{array}{l}-0.005 \\
(-0.108)\end{array}$ & $\begin{array}{c}-0.018 \\
(-0.463)\end{array}$ & $\begin{array}{c}0.008 \\
(0.194)\end{array}$ & $\begin{array}{c}0.035 \\
(0.828)\end{array}$ \\
\hline Constant & $\begin{array}{c}0.377^{* *} \\
(2.326)\end{array}$ & $\begin{array}{c}0.187 \\
(1.092)\end{array}$ & $\begin{array}{c}0.259 \\
(1.585)\end{array}$ & $\begin{array}{c}0.761^{* *} \\
(2.419)\end{array}$ & $\begin{array}{r}0.547^{*} \\
(1.669)\end{array}$ & $\begin{array}{c}0.715^{\text {*** }} \\
(2.178)\end{array}$ \\
\hline$N$ & 2,007 & 2,007 & 2,007 & 1,814 & 1,814 & 1,814 \\
\hline Adj. $R^{2}$ & 0.771 & 0.765 & 0.774 & 0.707 & 0.709 & 0.712 \\
\hline
\end{tabular}

Notes:

Investment cycle measures the length of the investment cycle, computed as the industry average of the depreciation expense divided by the lagged total assets, multiplied by (-1) (see Khan and Watts, 2009). The dependent variable is the 12-month buy-hold return (raw) (RET). $\triangle E P S$ is the change in the EPS from year $t-1$ to year $t$ and EPS is the earnings per share deflated by the stock price at the beginning of the year. $S A M P$ equals 1 if the firm is a treatment firm, and 0 otherwise. EXP equals 1 if the data year is after the exposure of the corrupt official, and 0 otherwise. We use firm-year observations from 5 years before to 5 years after the corruption exposure years and exclude the corruption exposure years. The industry and year fixed effects are included in all of the regressions. *,** and *** denote significance at the $10 \%, 5 \%$ and $1 \%$ levels, respectively. The $t$-statistics in parentheses are based on the standard errors clustered by firm.

larger disruption in these firms' earning persistence. We expect that the increase in the earnings informativeness after the exposure of the corruption scandals will be smaller than in firms that rely less on external financing. We follow Rajan and Zingales (1998) and Klapper, Laeven and Rajan (2006) to measure the firms' dependence on external financing as the industry average ratio of capital expenditures minus the cash flow from operations with the difference deflated by the capital expenditures. We find that firms with political networks observe a smaller increase in their ERCs when they are more dependent on external financing after the corruption scandals than their control firms, measuring the ERC using either the change in or the level of the earnings (results not tabulated). If both the change in and level of the earnings 
are included in the model, only the earnings level shows a coefficient change that is consistent with the valuation effect.

In summary, this section provides evidence that political networks have both a valuation and measurement effect on the earnings. Our results suggest that the measurement effect is the dominant effect (Table 4). However, as our research design cannot separately and accurately identify the two effects, the results here should be interpreted as indicative but not dispositive. A future analysis using a more powerful setting is needed to better understand their relative importance.

\section{(v) Robustness Checks}

We conduct robustness checks on our main results.

We control for the effect of earnings management by using the earnings from continuing operations to calculate the change in the EPS in our main regression (equation (2)). The estimation results are reported in Table 7, Panel A. The results are very similar to the main results based on the bottom-line net income reported in Table 4 . The coefficients on the interaction term $\triangle E P S \times S A M P \times E X P$ are all positive and statistically significant at the $5 \%$ level or better.

For the dependent variable stock returns we follow prior research (e.g., Francis et al., 2005; Hanlon et al., 2008) and use the raw returns in our main tests in Table 4. We test whether our results are robust to the use of market adjusted abnormal returns. The results are reported in Table 7, Panel B. For all of the tests, our findings are similar to those in the main tests.

Prior research indicates that a number of factors may affect the ERC. Hayn (1995), for example, suggests that the ERC of negative earnings is generally smaller than that of positive earnings. Using the firm size as a proxy for firms' general information environment, Atiase (1985) finds that large firms have a lower average ERC than smaller firms. Easton and Zmijewski (1989) propose that risk negatively affects the ERC by increasing the equity discount rate. Collins and Kothari (1989) predict a positive association between a firm's growth opportunities and its ERC. We confirm that our results are not confounded by these factors by including their proxies as additional controls in the regression as a sensitivity test. We include the firm size (SIZE), leverage $(L E V)$, and stock return volatility (STDRET) as proxies for the firm risk; an indicator variable (LOSS) to denote whether a firm has negative profits; and Tobin's $Q$ to proxy for a firm's growth opportunities. We report the regression results in Table 8 . The coefficients on our main variable of interest, the three-way interaction term $\triangle E P S \times$ $S A M P \times E X P$, are all positive and significant at the conventional level.

We also consider whether there is any change in the firms' general disclosure policies, as proxied by the R-square of the market model (Morck et al., 2000; Gul et al., 2010). This R-square measure reflects the extent to which stock prices reflect the firm-specific information disclosed through information channels and can therefore be used as a summary statistic of the firm's general disclosure. A higher R-squared indicates poorer firm-specific disclosure. Univariate comparisons reveal that politically connected firms show no significant change in their market model R-squareds around the exposure of the scandals (results not tabulated), suggesting no overall change in the firm disclosure policies. Including this variable in the regression does not change our conclusions. 


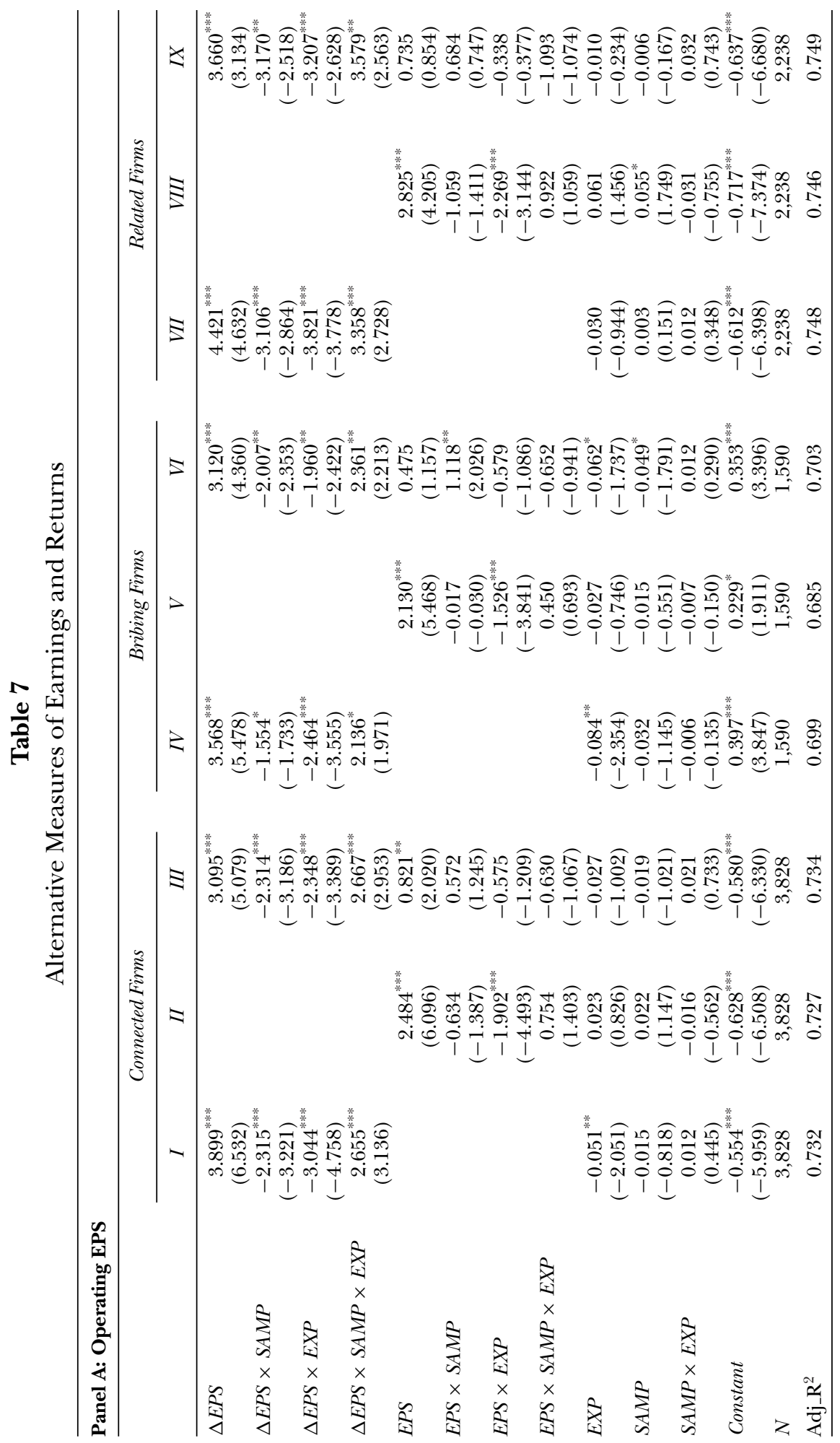




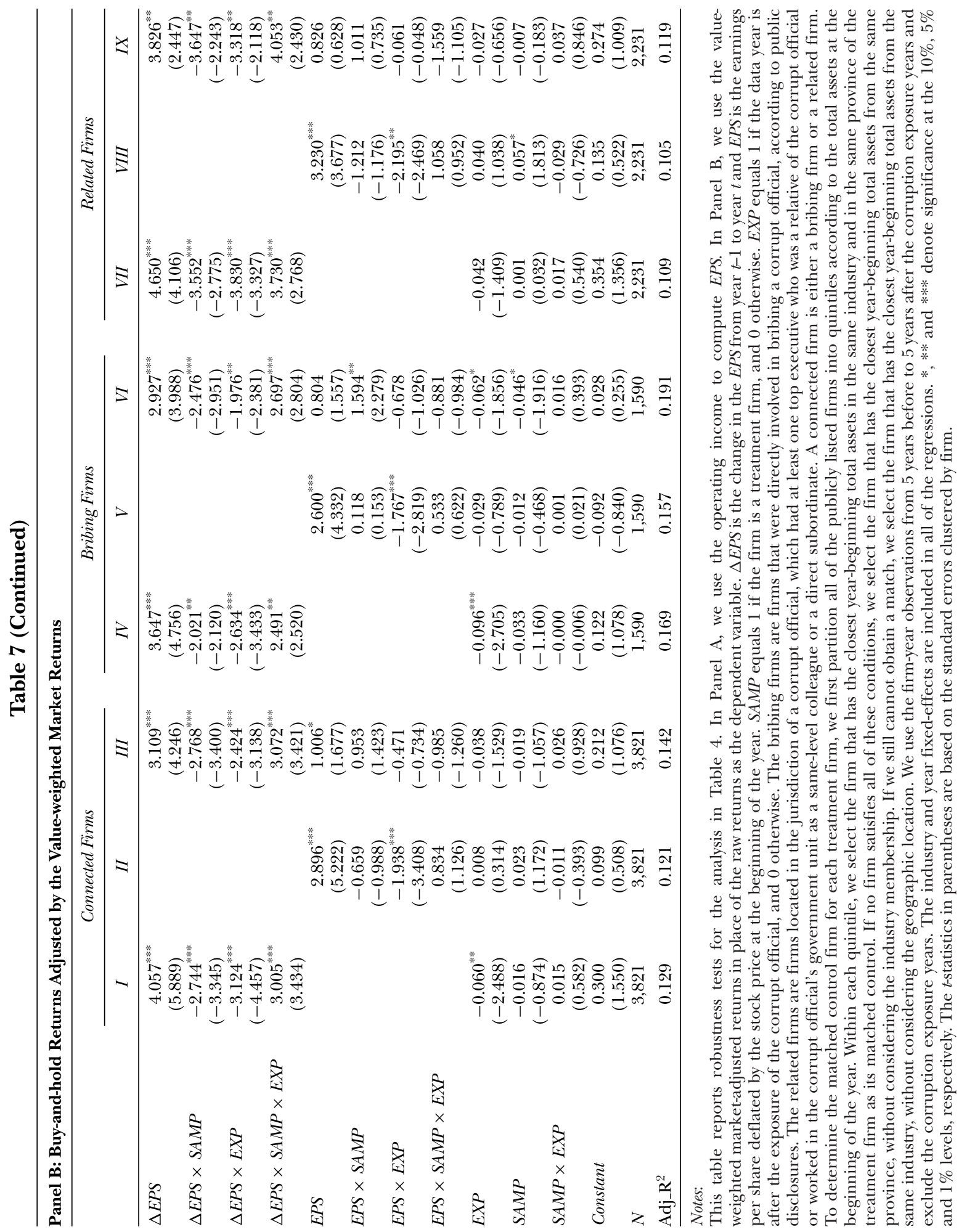




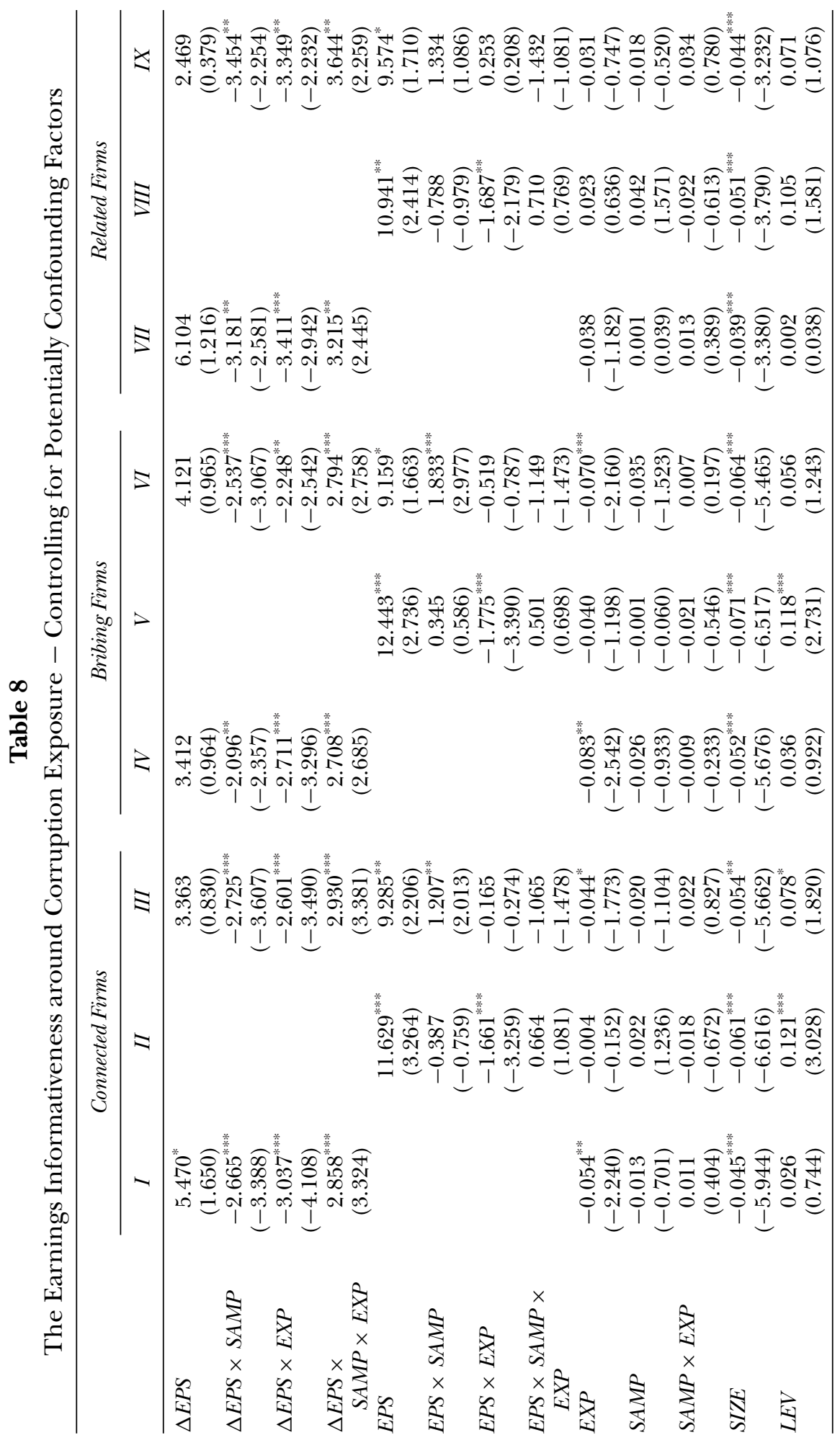




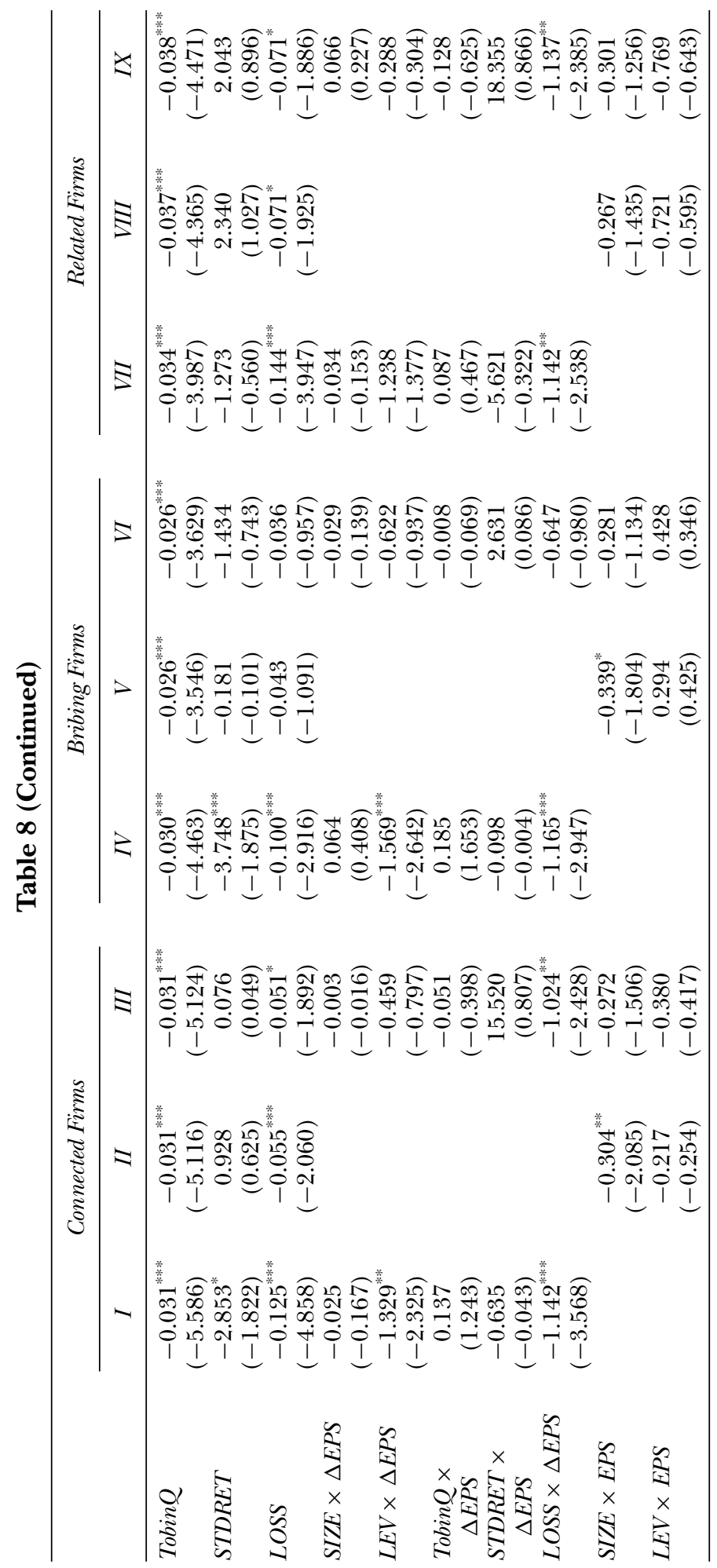




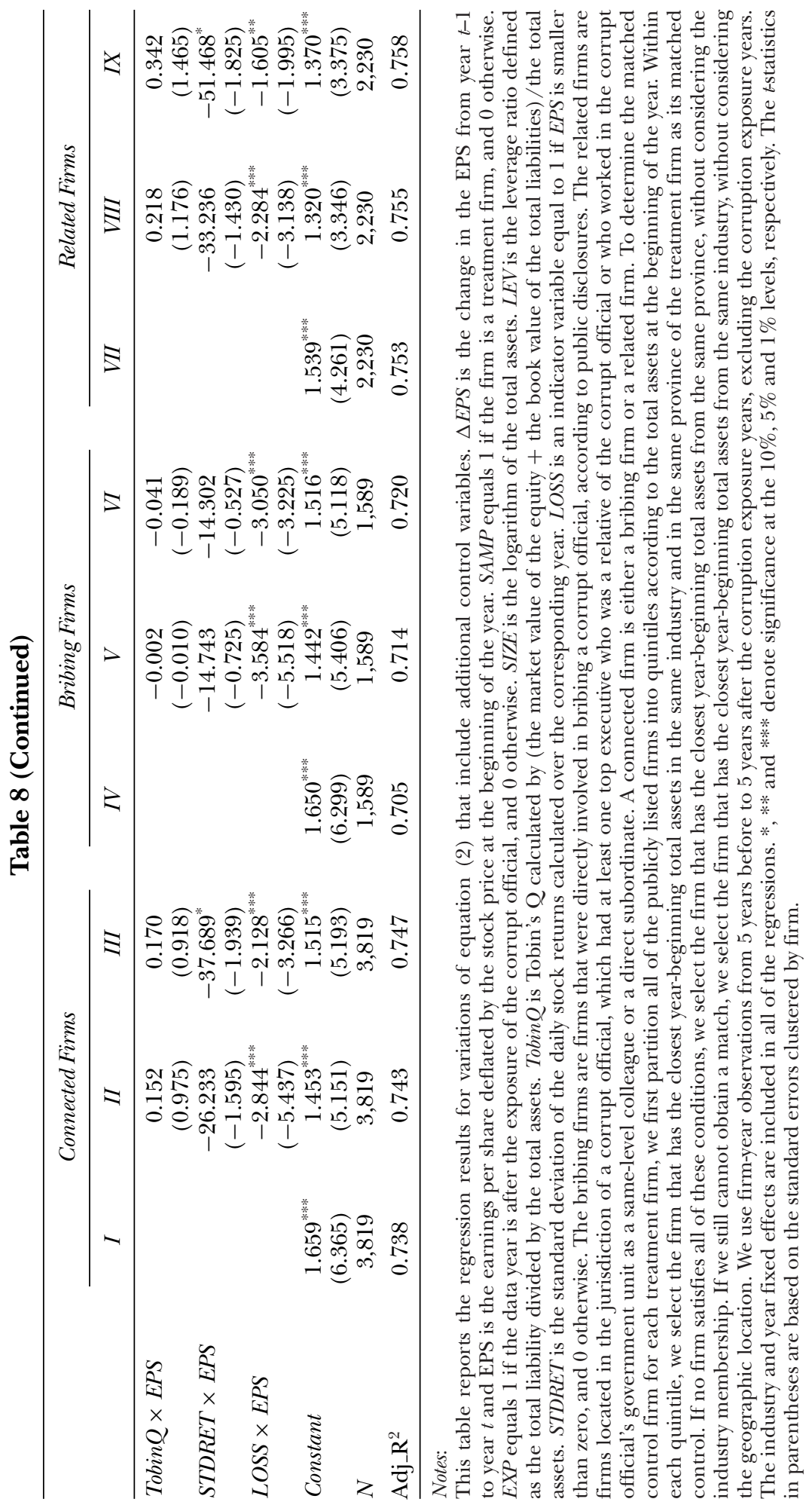


In our main analysis, the magnitude of the ERC is affected by the standard deviation of the earnings and returns. We investigate how our inferences based on the relative magnitude of the ERC are affected by the variance of the relevant variables by reestimating the regressions in Table 4 using standardized variables. The average ERC for the control firms now changes from 0.468 before the exposure of the scandals to 0.135 after the scandals are exposed, whereas the average ERC of the treatment (connected) firms changes from 0.223 to 0.109 (results not tabulated). Although the relative difference in the average ERC between the treatment and control firms prescandal exposure is smaller than when using unstandardized variables (treatment: 4.270 vs. control: 1.428), it is still substantial. Our conclusions therefore remain largely the same.

An alternative way to measure the earnings informativeness is to study the incremental explanatory power of the earnings for the stock returns. However, Brown et al. (1999) and $\mathrm{Gu}$ (2002) note that it is problematic to compare the R-squared across samples. We thus follow the literature and rely on the ERC to draw inferences in our main tests. When we estimate regressions of the stock returns on the year fixed effects and both the change in and level of earnings (untabulated), we find that the partial R-squared of the earnings decreases from $17.5 \%$ pre-scandal exposure to $4.2 \%$ postscandal exposure in the control firms. ${ }^{7}$ In contrast, the partial R-squared decreases from only $10.7 \%$ to $4.2 \%$ in the connected firms. This pattern of change in the partial $\mathrm{R}$-squared is consistent with the change in the ERC from the pre- to the post-scandal exposure period for the two subsamples.

\section{CONCLUSIONS}

The accounting opacity observed in firms in emerging markets is not only due to conflicts of interest and the cover-up of rent-seeking activities, as discussed in the literature (Ball et al., 2000, 2003; Fan and Wong, 2002), but is also due to the measurement difficulties for network-based assets which are prevalent in these markets. We hypothesize that the break of a political network reduces the extent of network-based dealings, lessens problematic measurement issues, and thus improves the informativeness of the accounting numbers describing the firm's economic performance. We test this hypothesis by exploiting a natural experiment, examining publicly traded firms involved in 45 high-profile corruption scandals in China. Anticorruption enforcement against high-level bureaucrats in China is generally triggered by conditions that are not related to corporate operations and hence serves as an exogenous shock. Our evidence demonstrates that the earnings informativeness of firms connected with corrupt bureaucrats improves after these bureaucrats are exposed.

We find little evidence to indicate that the recorded relative improvement in the earnings informativeness is due to a lower level of earnings management following the scandals. Our results reveal that political networks are likely to have both a valuation effect, which increases the earnings persistence and hence the earnings informativeness of the firm value, and a measurement effect, which decreases the

7 The partial $\mathrm{R}^{2}$ is calculated by $\left(R_{y, x}^{2}-R_{y, x 1}^{2}\right) /\left(1-R_{y, x 1}^{2}\right)$ where $y$ the dependent variable, the vector $x$ includes the $\triangle E P S, E P S$ and year dummies, and the vector $x 1$ includes only the year dummies. 
earnings informativeness. Our results suggest that the measurement effect dominates the valuation effect.

Our findings have important implications for the international investment community. To better track firms' values and economic performance, investors should adjust the extent of their reliance on financial information in countries in which networktype assets play an important role. The financial information in emerging markets is likely to be less informative than in developed markets, which are characterized primarily by market-based transactions. Due to the special nature of network-based assets, no market can be leveraged to accurately assess their value. The existing accounting systems therefore cannot effectively resolve their measurement issues. In these economies, non-financial information may be especially important for gauging firm values.

\section{REFERENCES}

Aboody, D. and B. Lev (1998), 'The Value Relevance of Intangibles: The Case of Software Capitalization', Journal of Accounting Research, Vol. 36, pp. 161-91.

Allen, F. and A. Babus (2009), 'Networks in Finance', in Chapter 21 of Paul Kleindorfer and Jerry Wind (eds.), Network-based Strategies and Competencies (New Jersey: Wharton School Publishing), pp. 367-82.

Atiase, R. (1985), 'Predisclosure Information, Firm Capitalization, and Security Price Behavior around Earnings Announcements', Journal of Accounting Research, Vol. 23, pp. 21-36.

Bae, K. and S. W. Jeong (2007), 'The Value-Relevance of Earnings and Book Value, Ownership Structure, and Business Group Affiliation: Evidence from Korean Business Groups', Journal of Business Finance and Accounting, Vol. 34, pp. 740-66.

Ball, R., A. Robin and J. Wu (2003), 'Incentives versus Standards: Properties of Accounting Income in four East Asian Countries', Journal of Accounting and Economics, Vol. 36, pp. 23570.

- S. P. Kothari and A. Robin (2000), 'The Effect of International Institutional Factors on Properties of Accounting Earnings', Journal of Accounting and Economics, Vol. 29, pp. 1-51.

Bao, B. and D. Bao (2004), 'Income Smoothing, Earnings Quality and Firm Valuation', Journal of Business Finance and Accounting, Vol. 31, pp. 1,525-57.

Barron, O. E., D. Byard, C. Kile and E. Riedl (2002), 'High-Technology Intangibles and Analysts' Forecasts', Journal of Accounting Research, Vol. 40, pp. 289-312.

Barth, M. E., M. B. Clement, G. Foster and R. Kasznik (1998), 'Brand Values and Capital Market Valuation', Review of Accounting Studies, Vol. 3, pp. 41-68.

Brown, S., K. Lo and T. Lys (1999), 'Use of R2 in Accounting Research: Measuring Changes in Value Relevance over the Last Four Decades', Journal of Accounting and Economics, Vol. 28, pp. 83-115.

Bunkanwanicha, P., J. P. H. Fan and Y. Wiwattanakantang (2009), Why do Shareholders Value Marriage? Working Paper, The Chinese University of Hong Kong.

Bushman, R. M. and J. D. Piotroski (2006), 'Financial Reporting Incentives for Conservative Accounting: The Influence of Legal and Political Institutions', Journal of Accounting and Economics, Vol. 1-2, pp. 107-48.

— J. D. Piotroski and A. J. Smith (2006), 'What Determines Corporate Transparency?' Journal of Accounting Research, Vol. 42, pp. 207-52.

Chaney, P. K., M. Faccio and D. Parsley (2011), 'The Quality of Accounting Information in Politically Connected Firms', Journal of Accounting and Economics, Vol. 51, pp. 58-76.

Charitou, A., C. Clubb and A. Andreou (2001), 'The Effect of Earnings Permanence, Growth and Firm Size on the Uusefulness of Cash Flows and Earnings in Explaining Security Returns: Empirical Evidence for the UK', Journal of Business Finance and Accounting, Vol. 28, pp. 563-94.

Charumilind, C., R. Kali and Y. Wiwattanakantang (2006), 'Connected Lending: Thailand before the Financial Crisis', Journal of Business, Vol. 79, pp. 181-217. 
Chen, K. and H. Yuan (2004), 'Earnings Management and Capital Resource Allocation: Evidence from China's Accounting-based Regulation of Rights Issues', Accounting Review, Vol. 79, pp. 645-65.

Christensen, H. B., E. Lee and M. Walker (2007), 'Cross-sectional Variation in the Economic Consequences of International Accounting Harmonization: The Case of Mandatory IFRS Adoption in the UK', The International Journal of Accounting, Vol. 42, pp. 341-79.

Claessens, S., E. Feijen and L. Laeven (2008), 'Political Connections and Preferential access to Finance: The Role of Campaign Contributions',Journal of Financial Economics, Vol. 88, pp. 554-80.

Cohen, L., A. Frazzini and C. Malloy (2007), 'The Small World of Investing: Board Connections and Mutual Fund Returns', Working Paper No. 13121 (Cambridge, MA: NBER).

Collins, D. W. and S. P. Kothari (1989), 'An Analysis of Intertemporal and Cross-Sectional Determinants of Earnings Response Coefficients', Journal of Accounting and Economics, Vol. 12, pp. 143-81.

_ E. L. Maydew and I. S. Weiss (1997), 'Changes in the Value-Relevance of Earnings and Book Values over the Past Forty Years', Journal of Accounting and Economics, Vol. 24, pp. 3967.

Dechow, P. M., S. A. Richardson and I. Tuna (2003), 'Why are Earnings Kinky? An Examination of the Earnings Management Explanation', Review of Accounting Studies, Vol. 8, pp. 355-84.

DeFond, M., M. Y. Hung and R. Trezevant (2007), 'Investor Protection and the Information Content of Annual Earnings Announcements: International Evidence', Journal of Accounting and Economics, Vol. 1, pp. 37-67.

Easton, P. and M. Zmijewski (1989), 'Cross-Sectional Variation in the Stock Market Response to Accounting Earnings Announcements', Journal of Accounting and Economics, Vol. 11, pp. $117-41$.

Easton, P. D. and T. S. Harris (1991), 'Earnings as an Explanatory Variable for Returns', Journal of Accounting Research, Vol. 29, pp. 19-36.

Elliott, R. (1995), 'The Future of Assurance Services: Implications for Academia', Accounting Horizon, Vol. 9, pp. 118-27.

Faccio, M. (2006), 'Politically Connected Firms', American Economic Review, Vol. 1, pp. 369-386.

Fan, J. P. H. and T. J. Wong (2002), 'Corporate Ownership Structure and the Informativeness of Accounting Earnings in East Asia', Journal of Accounting and Economics, Vol. 33, pp. 401-25.

- , O. Rui and M. Zhao (2008), 'Public Governance and Corporate Finance: Evidence from Corruption Cases', Journal of Comparative Economics, Vol. 36, pp. 343-64.

Fisman, R. (2001), 'Estimating the Value of Political Connections', American Economic Review, Vol. 91, pp. 1,095-1,102.

Francis, J. and K. Schipper (1999), 'Have Financial Statements Lost their Value Relevance?' Journal of Accounting Research, Vol. 37, pp. 319-51.

, K. Schipper and L. Vincent (2005), 'Earnings and Dividend Informativeness when Cash Flow Rights are Separated from Voting Rights', Journal of Accounting and Economics, Vol. 39, pp. 329-60.

Graham, R. C., C. E. Lefanowicz and K. R. Petroni (2003), 'The Value Relevance of Equity Method Fair Value Disclosures', Journal of Business Finance and Accounting, Vol. 30, pp. 1,06588.

$\mathrm{Gu}$, Z. (2002), 'Across-sample Incomparability of R2s and Additional Evidence on Value Relevance Changes Over Time', Journal of Business Finance and Accounting, Vol. 34, pp. 1,07398.

Gul, F. A., J. B. Kim and A. Qiu (2010), 'Ownership Concentration, Foreign Shareholding, Audit Quality and Stock Price Synchronicity: Evidence from China', Journal of Financial Economics, Vol. 95, pp. 425-42.

Hanlon, M., E. L. Maydew and T. Shevlin (2008), 'An Unintended Consequence of Book-tax Conformity: A Loss of Earnings Informativeness', Journal of Accounting and Economics, Vol. 46, pp. 294-311.

Haw, I. M., D. Qi, D. Wu and W. Wu (2005), 'Market Consequences of Earnings Management in Response to Security Regulations in China', Contemporary Accounting Research, Vol. 22, pp. $95-140$. 
Hayn, C. (1995), 'The Information Content of Losses', Journal of Accounting and Economics, Vol. 20, pp. $125-53$.

Hochberg, Y., A. Ljungqvist and Y. Lu (2007), 'Whom you Know Matters: Venture Capital Networks and Investment Performance', Journal of Finance, Vol. 62, pp. 251-301.

Holthausen, R. W. and R. E. Verrecchia (1988), 'The Effect of Sequential Information Releases on the Variance of Price Changes in an Intertemporal Multi-asset Market', Journal of Accounting Research, Vol. 26, pp. 82-106.

Hui, K. W., C. S. Lennox and G. Zhang (2014), 'The Market's Valuation of Fraudulently Reported Earnings', Journal of Business Finance and Accounting, forthcoming.

Ittner, C. D. and D. F. Larcker (1998), 'Are Nonfinancial Measures Leading Indicators of Financial Performance? An Analysis of Customer Satisfaction', Journal Accounting Research, Vol. 36, pp. 1-35.

Jenkins, D. S., G. D. Kane and U. Velury (2009), 'Earnings Conservatism and Value Relevance across the Business Cycle', Journal of Business Finance and Accounting, Vol. 36, pp. 1,041-58.

Jian, M. and T. J. Wong (2010), 'Propping through Related Party Transactions', Review of Accounting Studies, Vol. 15, pp. 70-105.

Johnson, S. and T. Mitton (2003), 'Cronyism and Capital Control: Evidence from Malaysia', Journal of Financial Economics, Vol. 67, pp. 351-82.

Kanodia, C., H. Sapra and R. Venugopalan (2004), 'Should Intangibles be Measured: What are the Economic Trade-offs?' Journal of Accounting Research, Vol. 42, pp. 89-120.

Khan, M. and Watts, R. L. (2009), 'Estimation and Empirical Properties of a Firm-Year Measure of Accounting Conservatism', Journal of Accounting Economics, Vol. 48, pp. 132-50.

Khanna, T. and C. Thomas (2009), 'Synchronicity and Firm Interlocks in an Emerging Market', Journal of Financial Economics, Vol. 92, pp. 182-204.

Khwaja, A. I. and A. Mian (2005), 'Do Lenders Favor Politically Connected Firms? Rent-Seeking in an Emerging Financial Market', Quarterly Journal of Economics, Vol. 120, pp. 1,371-1,411.

Klapper, L., L. Laeven and R. Rajan (2006), 'Entry Regulation as a Barrier to Entrepreneurship', Journal of Financial Economics, Vol. 82, pp. 591-629.

Klein, B. and K. B. Leffler (1981), 'The Role of Market Forces in Assuring Contractual Performance', Journal of Political Economics, Vol. 89, pp. 615-41.

Kothari, S. P. (2001), 'Capital Markets Research in Accounting', Journal of Accounting and Economics, Vol. 31, pp. 105-231.

— A. J. Leone and C. E. Wasley (2005), 'Performance Matched Discretionary Accrual Measures', Journal of Accounting and Economics, Vol. 39, pp. 163-97.

Leuz, C. and F. Oberholzer-Gee (2006), 'Political Relationships, Global Financing, and Corporate Transparency: Evidence from Indonesia', Journal of Financial Economics, Vol. 81, pp. 411-39.

- D. Nanda and P. D. Wysocki (2003), 'Earnings Management and Investor Protection: An International Comparison', Journal of Financial Economics, Vol. 69, pp. 505-27.

Lev, B. and P. Zarowin (1999), 'The Boundaries of Financial Reporting and How to Extend Them', Journal of Accounting Research, Vol. 37, pp. 353-85.

and T. Sougiannis (1996), 'The Capitalization, Amortization, and Value-relevance of R\&D', Journal of Accounting and Economics, Vol. 21, pp. 107-38.

Marquardt, C. A. and C. I. Wiedman (2004), 'The Effect of Earnings Management on the Value Relevance of Accounting Information', Journal of Business Finance and Accounting, Vol. 31, pp. 297-332.

McMillan, J. and C. Woodruff (1999), 'Interfirm Relationships and Informal Credit in Vietnam', Quarterly Journal of Economics, Vol. 114, pp. 1,285-1,320.

Morck, R., B. Yeung and W. Yu (2000), 'The Information Content of Stock Markets: Why do Emerging Markets have Synchronous Stock Price movements?' Journal of Financial Economics, Vol. 58, pp. 215-60.

$\mathrm{Ou}, \mathrm{J}$. A. and J. F. Sepe (2002), 'Analysts Earnings Forecasts and the Roles of Earnings and Book Value in Equity Valuation', Journal of Business Finance and Accounting, Vol. 29, pp. 287-316.

Rajan, R. and L. Zingales (1998), 'Financial Dependence and Growth', American Economic Review, Vol. 88, pp. 559-86.

Rimerman, T. W. (1990), 'The Changing Significance of Financial Statements', Journal of Accountancy, Vol. 79, pp. 82-103. 
Stewart, T. A. (1997), Intellectual Capital: The Wealth of Organizations, New York: Doubleday/Currency.

Teoh, S. H. and T. J. Wong (1993), 'Perceived Auditor Quality and the Earnings Response Coefficient', The Accounting Review, Vol. 68, pp. 346-66.

Walker, M. (2010), 'Accounting for Varieties of Capitalism: The Case against a Single set of Global Accounting Standards', The British Accounting Review, Vol. 42, pp. 137-52.

Wallman, S. H. (1995), 'The Future of Accounting and Disclosure in an Evolving World: The Need for Dramatic Change', Accounting Horizons, Vol. 9, pp. 81-91.

Wang, L. and K. Yung (2011), 'Do State Enterprises Manage Earnings more than Privately Owned Firms? The Case of China', Journal of Business Finance and Accounting, Vol. 38, pp. 794-812.

Wiedman, C. I. and K. B. Hendricks (2013), 'Firm Accrual Quality following Restatements: A Signaling View', Journal of Business Finance and Accounting, Vol. 40, pp. 1,095-1,125.

Wieland, M. W., M. C. Dawkins and M. T. Dugan (2013), 'The Differential Value Relevance of S\&P's Core Earnings Versus GAAP Earnings: The Role of Stock Option Expense', Journal of Business Finance and Accounting, Vol. 40, pp. 5-81.

Williamson, O. E. (1985), The Economic Institutions of Capitalism: Firms, Markets, Relational Contracting, New York: The Free Press. 